\title{
Carl Linnaeus and the Visual Representation of Nature
}

\begin{abstract}
The Swedish naturalist Carl Linnaeus (1707-1778) is reputed to have transformed botanical practice by shunning the process of illustrating plants and relying on the primacy of literary descriptions of plant specimens. Botanists and historians have long debated Linnaeus's capacities as a draftsman. While some of his detailed sketches of plants and insects reveal a sure hand, his more general drawings of landscapes and people seem ill-executed. The overwhelming consensus, based mostly on his Lapland diary (1732), is that Linnaeus could not draw. Little has been said, however, on the role of drawing and other visual representations in Linnaeus's daily work as seen in his other numerous manuscripts. These manuscripts, held mostly at the Linnean Society of London, are peppered with sketches, maps, tables, and diagrams. Reassessing these manuscripts, along with the printed works that also contain illustrations of plant species, shows that Linnaeus's thinking was profoundly visual and that he routinely used visual representational devices in his various publications. This paper aims to explore the full range of visual representations Linnaeus used through his working life, and to reevaluate the epistemological value of visualization in the making of natural knowledge. By analyzing Linnaeus's use of drawings, maps, tables, and diagrams, I will show that he did not, as has been asserted, reduce the discipline of botany to text, and that his visual thinking played a fundamental role in his construction of new systems of classification.
\end{abstract}

KEY WORDS: Linnaeus, natural history, drawing, visual representations, manuscripts, printed books

* Centre for Medical History, University of Exeter, Rennes Drive, Amory Building, Exeter, UK EX4 4RJ; I.Charmantier@exeter.ac.uk.

The following abbreviation is used: LS, Library of the Linnean Society of London, U.K.

Historical Studies in the Natural Sciences, Vol. 4I, Number 4, pps. 365-404. ISSN 1939-18II, electronic ISSN 1939-182X. (C) 201 ir by the Regents of the University of California. All rights reserved. Please direct all requests for permission to photocopy or reproduce article content through the University of California Press's Rights and Permissions website, http://www. ucpressjournals.com/reprintinfo.asp. DOI: I0.1525/hsns.20II.4I.4.365. 
Who in his right mind would condemn pictures which can communicate information much more clearly than the words of even the most eloquent men?

Those things that are presented to the eyes and depicted on panels or paper become fixed more firmly in the mind than those that are described in bare words.

$$
\text { Leonard Fuchs, De Historia Stirpium (1542) }{ }^{1}
$$

In the first edition of Genera Plantarum, printed in Leiden in 1737 , the Swedish naturalist Carl Linnaeus (1707-1778) famously wrote in his typical no-nonsense style:

I do not recommend drawings to determine genera, in fact I absolutely reject them, although I confess that they are of great importance to boys and those who have more brainpan than brain; I confess that they convey something to the unlearned. . . . We will therefore try to express by words all marks just as clearly_-if not more clearly-as others with their splendid drawings. ${ }^{2}$

The importance of artists and artisans as integral to the scientific revolution has been convincingly demonstrated in the last few years, as has the role of images as vehicles of scientific knowledge on par with words and instruments. ${ }^{3}$ Many studies stress the rise and importance of pictorial and diagrammatic representations in science throughout early modern Europe. Kärin Nickelsen's work has emphasized the function of botanical illustrations as models in the eighteenth century: "Botanical images ... do not show the outer appearance of living plants but rather depict models of botanical species, characterized by a set of typical properties" which were themselves "defined by the prevalent taxonomic system."

I. Quoted in James S. Ackerman, "Early Renaissance 'Naturalism' and Scientific Illustration," in The Natural Sciences and the Arts: Aspects of Interaction from the Renaissance to the 20th Century (Uppsala: Acta Universitatis Upsaliensis, 1985), I7.

2. Staffan Müller-Wille and Karen Reeds, "A Translation of Carl Linnaeus's Introduction to Genera Plantarum (1737)," Studies in History and Philosophy of Science Part C: Studies in History and Philosophy of Biological and Biomedical Sciences 38, no. 3 (2007): 563-72, on 568.

3. Lorraine Daston, "On Scientific Observation," Isis 99, no. I (2008): 97-IIO; Lorraine Daston and Peter Galison, "The Image of Objectivity," Representations 40 (1992): 8I-I28; Sachiko Kusukawa, "Illustrating Nature," in Books and the Sciences in History, ed. Marina Frasca-Spada and Nick Jardine (Cambridge: Cambridge University Press, 2000); Pamela H. Smith, "Art, Science, and Visual Culture in Early Modern Europe," Isis 97, no. I (2006): 83-Ioo; Claudia Swan, "From Blowfish to Flower Still Life Painting: Classification and Its Images, circa I600," in Merchants and Marvels: Commerce, Science, and Art in Early Modern Europe, ed. Pamela H. Smith and Paula Findlen (New York: Routledge, 2002)

4. Kärin Nickelsen, "Draughtsmen, Botanists and Nature: Constructing EighteenthCentury Botanical Illustrations," Studies in History and Philosophy of Science Part C: Studies in History and Philosophy of Biological and Biomedical Sciences 37, no. I (2006): I-25, on 22. 
For some historians, Linnaeus's virulent attack on drawings typifies the decline in the use of imagery in eighteenth-century science. It signals in effect the end of the priority given to visual representations in science. ${ }^{5}$ As this essay shall show, however, Linnaeus's comment was specifically meant for the use of images to depict genera. Linnaeus actually used and advocated the use of illustrations throughout his career, especially to depict species of plants. Moreover, his thinking was profoundly visual-he routinely used map metaphors and highly visual representational devices in his various publications.

Previous studies on Linnaeus's visual representations have mainly focused on his drawings. Opinions are divided about whether Linnaeus was a good or bad draftsman (Brit var. "draughtsman"). Felix Bryk thought that Linnaeus was an "excellent draughtsman." William Stearn had a more mitigated opinion and noted that Linnaeus was "a good draughtsman when dealing with small objects": "Those [sketches] illustrating large objects are admittedly crude; those illustrating small objects are much better, being more sensitive and accurate. . . . Spencer Savage has suggested that this difference in quality was due to Linnaeus's myopia."7 Conversely, both Wilfrid Blunt and Karen Reeds thought Linnaeus's drawing skills were pitiful. Blunt noted scathingly: "Matisse once said that his ambition was to draw like his little girl of five; Linnaeus achieved this effortlessly," while Reeds maintained that "Linnaeus himself was laughably inept at drawing." 8 She found the "vehemence" of the passage from Genera Plantarum "striking" and further noted that Linnaeus "built his system around his own extraordinary talents as an observer and describer" in part because he was such a bad draftsman. ' While Reeds made more allowance than Blunt did for the difficult conditions in which Linnaeus had to draw, particularly during his Lapland journey, and while both criticisms

5. Nils Ekedahl, "Collecting Flowers: Linnaean Method and the Humanist Art of Reading," Acta Universitatis Upsaliensis: Symbolae Botanicae Upsalienses, special issue, "Species Plantarum 250 Years," Proceedings of the Species Plantarum Symposium held in Uppsala August 22-24, 2003, 33, no. 3 (Uppsala: Uppsala Universitet, 2005): 47-60, on 56; David Freedberg, The Eye of the Lynx: Galileo, His Friends and the Beginnings of Modern Natural History (Chicago: University of Chicago Press, 2002), 412-13. See also Walter J. Ong, Orality and Literacy: The Technologizing of the Word (London: Methuen, 1982).

6. Cited in Wilfrid Blunt, The Compleat Naturalist: A Life of Linnaeus (London: Collins, I97I), 52.

7. W. T. Stearn, Carl Linnaeus: Species Plantarum: A Facsimile of the First Edition I753, vol. I (London: Ray Society, 1957), 64.

8. Blunt, Compleat Naturalist (ref. 6), 52; Karen Meier Reeds, "When the Botanist Can't Draw: The Case of Linnaeus," Interdisciplinary Science Reviews 29, no. 3 (2004): 248-58, on 249.

9. Reeds, "When the Botanist Can't Draw" (ref. 8), 257. 
are perhaps correct in their aesthetic evaluation of the drawings, both are misguided in the understanding of Linnaeus's intentions. This article aims to show that Linnaeus's interest-or lack thereof — in drawing was not absolute but relative to the practical context, that is, the actual purpose for which the drawings were made. Reeds believes that Linnaeus built his work upon literary observations and descriptions because he could not draw and that "once the Hortus Cliffortianus was finished [i.e., 1737], he had nothing more to do with illustrations of actual plants. Diagrams, yes, but only to explain technical terms. Henceforth, words, not pictures, would drive botany." ${ }^{10}$ My contention is that Linnaeus never found it necessary to learn how to draw because he never found it adequate for his purpose, which was to establish the relations between taxa in all kingdoms of nature-first through his artificial, or sexual, system, and later on through his attempt at a system of "natural" genera and orders. Moreover, Linnaeus never completely abandoned botanical illustration and continued to use illustrations of plants in other contexts, notably when it came to the description of new species.

If one wishes to regard Linnaeus's drawings skills as poor, there are various factors that could be referred to by way of explanation. The hypothesis that Linnaeus was color blind has been raised recently, and might explain why all of his drawings are in black and white and tend to concentrate solely on the contours of things. ${ }^{11}$ Perhaps also Linnaeus never had the patience or the inclination to draw in detail. The tasks he set himself were considerable, necessitated efficiency and organization, and little time could be wasted in painstaking, meticulous drawings. Fascinated by Linnaeus's complex personality, historians and biographers who have tried to describe the character of the famous botanist have shown that patience does not seem to have been one of his strengths. ${ }^{12}$ In his second autobiography, the author described himself as follows: "Linnaeus ... was light, hasty, walked quickly, did everything promptly, could not stand late-comers, he was easily moved, sensitive. He worked continuously and could not spare himself."13 Regarding his

IO. Ibid.

II. E. C. Nelson, "The Enigma of the Sky-Blue Andromeda, or: Was Linnaeus Colourblind?," The Linnean 26, no. 3 (2010): 27-35.

I2. Sten Lindroth, "The Two Faces of Linnaeus," in Linnaeus: The Man and His Work, ed. Tore Frängsmyr, Uppsala Studies in History of Science (Canton, MA: Science History Publications/USA, 1994). See in particular Blunt, Compleat Naturalist (ref. 6), chap. 5.

I3. Elis Malmeström and Arvid Hj Uggla, eds., Vita Caroli Linnaei (Stockholm: Almqvist and Wiksell, 1957), 86. I thank Staffan Müller-Wille for translating the passage from Swedish. 
drawings, almost all are more akin to sketches than detailed illustrations. Linnaeus rarely seems to have used a microscope, for instance, relying rather on his eyes and his first impressions. "I myself . . . have examined all these plants with the naked eye, and without any use of a "microscopium," he boasted in Systema Naturae. ${ }^{14}$ Certainly, when one compares his work with that of other naturalists whose paperwork has been studied and analyzed, Linnaeus had a frugal approach to sketching, contenting himself with pencil, pen, ink, and paper against, for example, Hooke's paraphernalia of compass, magnifying glass, and knife. ${ }^{15}$

Furthermore, most of the seventeenth- and early eighteenth-century naturalists/ artists were either from a high social-economic background, where their education, like that of any elite, included drawing lessons, or from an artisan background. ${ }^{16}$ Both Charles Plumier, celebrated for his draftsmanship, and Maria Sibylla Merian, one of the finest entomological and botanical artists of the period, came from families of engravers and painters and were given a solid artistic education. ${ }^{17}$ In contrast, Linnaeus's father was a simple pastor and his son's education, reflecting a relatively poor background, in all likelihood did not include drawing lessons. A simple reason for Linnaeus's poor drawing skills might well be that he was never taught.

Ironically, it is probably the frequency with which Linnaeus had recourse to drawings and other visual representations in his manuscripts that has repeatedly given rise to the question of his drawing skills. Most of what has been written on Linnaeus's drawings overtly focuses on his Lapland diary, "Iter Lapponicum" (I732), a striking in-quarto manuscript, kept at the Linnean Society in London. ${ }^{18}$ Many of Linnaeus's other manuscripts, and especially those he wrote during his student years (I727-I735), are also filled with drawings and should be

14. Carl Linnaeus, Systema Naturae, I735: Facsimile of the First Edition (Utrecht, Neth.: Hes and De Graaf, 2003), 24.

15. Matthew Hunter, "Robert Hooke Fecit: Making and Knowing in Restoration London" (PhD dissertation, University of Chicago, 2007), 136-39.

16. On drawing as part of the education of the elite and aristocracy, see Ann Bermingham, Learning to Draw: Studies in the Cultural History of a Polite and Useful Art (New Haven, CT: Yale University Press, 2000).

17. Michel Thireau et al., "L'oeuvre ichtyologique de Charles Plumier aux Antilles (1689-1695)," in Explorations et voyages scientifiques de l'Antiquité à nos jours, ed. Christiane Demeulenaere-Douyère (Paris: Editions du CTHS, 2008), 47. For Merian, see Wilfrid Blunt, The Art of Botanical Illustration (London: Collins, 195I), I27; Natalie Zemon Davis, Women on the Margins: Three Seventeenth-Century Lives (Cambridge, MA: Harvard University Press, I995), I43.

I8. Carl Linnaeus, “Iter Lapponicum,” I732, LS, Box LM Trav. 
taken into consideration if one aims at a true evaluation of the quality and function of drawings in Linnaeus's oeuvre. Moreover, one cannot understand Linnaeus's use of drawings without considering the other kinds of visual representations in his work, such as tables, maps, and diagrams. ${ }^{19}$ The drawings in Linnaeus's works served the same function as these other visual representations. Taken together, they form a group of "scientific illustrations," which supplemented the text, replacing it completely or supporting it by giving it a visual form.

In relation to Linnaeus's visual arrangement of words and paragraphs in manuscripts and printed works, in particular in Philosophia Botanica (I75I), Matthew Eddy has recently emphasized the importance of commonplacing traditions. ${ }^{20}$ Eddy situates Linnaeus's visual representative practices (tables, lists, diagrams) within the Ramist tradition which held center stage in Protestant teaching practices, reinforcing other studies on early modern pedagogy that have stressed the importance of learning through methodical copying. ${ }^{21}$ In particular, selected readings were copied in commonplace books, or notebooks arranged thematically and according to title heads, also known as common places. Indeed, much of early modern scholarship_and not least in natural history-rested on organizational and memory skills learned on school benches. $^{22}$ The success of Ramism in Northern European countries has been stressed by Howard Hotson, and had reached Sweden by the beginning of the seventeenth century. ${ }^{23}$ Such pedagogical tools must have been used at Växjö gymnasium. ${ }^{24}$ In many ways, the young Linnaeus's visual tools were akin to

19. One of the rare works to do so is M. D. Eddy, "Tools for Reordering: Commonplacing and the Space of Words in Linnaeus's Philosophia Botanica," Intellectual History Review 20, no. 2 (2010): $227-52$.

20. Ibid.

2I. Ann Blair, "The Rise of Note-Taking in Early Modern Europe," Intellectual History Review 20, no. 3 (2010): 303-16; Ann Blair, Too Much to Know: Managing Scholarly Information before the Modern Age (New Haven, CT: Yale University Press, 20Io); Howard Hotson, Commonplace Learning: Ramism and Its German Ramifications, I543-I630 (Oxford: Oxford University Press, 2007); Ann Moss, Printed Commonplace-Books and the Structuring of Renaissance Thought (Oxford: Clarendon Press, 2002); Anke te Heesen, The World in a Box: The Story of an Eighteenth-Century Picture Encyclopedia (Chicago: University of Chicago Press, 2002).

22. See Paolo Rossi, Francis Bacon: From Magic to Science, trans. S. Rabinovitch (Chicago: Chicago University Press, 1968); Ann Blair, The Theatre of Nature: Jean Bodin and Renaissance Science (Princeton, NJ: Princeton University Press, 1997); Ann Blair, "Humanist Methods in Natural Philosophy: The Commonplace Book," Journal of the History of Ideas 53, no. 4 (I992): 54I-5I.

23. Hotson, Commonplace Learning (ref. 2I), 91.

24. See Ekedahl, "Collecting Flowers" (ref. 5). 
loci or topoi that were used for arranging wall-system libraries or providing overviews of encyclopedic texts. ${ }^{25}$ In a tradition inherited from the humanists and their commonplace books, order and systematic arrangement aided memory by encompassing the information within a single visual field. Linnaeus's diagrams, maps, tables, and drawings fit within this tradition of historia literaria. They aimed to provide an overview of knowledge as a basis for the generation of new knowledge.

It must be stressed, however, that in the fields which interested him — namely botany, medicine, and zoology — Linnaeus was first and foremost an autodidact. He learned from the tutors he acquired throughout his student years, but also from his own relentless reading. Linnaeus's first notebook, the "Ortabök" (I725), shows this quite well: his diagrams and tables are all copies of previously published works, which Linnaeus learned to adapt to his own research as time went on. ${ }^{26}$ Here, the dividing line between education and research breaks down and becomes more difficult to establish. As much as commonplacing techniques must have been central to Linnaeus's schooling and laid the foundations for his information processing methods, the visual practices which he developed ultimately went beyond the commonplacing tradition. They incited and supported a peculiar kind of visual thinking that became an essential part of Linnaeus's attempts to bring order to an ever-increasing amount of data about the natural world. ${ }^{27}$ Thus it will be shown that in the case of Linnaeus, certain visual tools enabled him to go beyond preconceived sets of headings which were a prerequisite of traditional commonplacing techniques.

Renzo Baldasso recently identified "the epistemological status of images and their value in the practice of science" as a glaring gap in the historiography of early modern scientific illustrations. ${ }^{28}$ Following Linnaeus at work and revealing how visual tools shaped his work and helped him envisage new ways

25. See Eric Garberson, "Libraries, Memory and the Space of Knowledge," Journal of the History of Collections I8 (2006): I05-36.

26. Some pages of the Örtabok are available online at http://www.vaxjo.se/ortaboken/bokrb.htm.

27. The cognitive function of visual thinking in human consciousness has been studied and emphasized by numerous scholars in the last few years. See Rudolf Arnheim, Art and Visual Perception: A Psychology of the Creative Eye (Berkeley: University of California Press, 2004); Martin Kemp, "Taking it on Trust: Form and Meaning in Naturalistic Representation," Archives of Natural History 17, no. 2 (1990): 127-88; David Topper, "Towards an Epistemology of Scientific Illustration," in Picturing Knowledge: Historical and Philosophical Problems Concerning the Use of Art in Science, ed. Brian S. Baigrie (Toronto: University of Toronto Press, 1996).

28. Renzo Baldasso, "The Role of Visual Representation in the Scientific Revolution: A Historiographic Inquiry," Centaurus 48, no. 2 (2006): 69-88, on 85. 
of understanding the natural world can contribute to closing this gap. In other words, my focus will lie not on the representations themselves, but on what Chiara Ambrosio calls "representative practices," emphasizing the practice of drawing up visual representation as a process of making knowledge, not solely of presenting and memorizing digested learning. ${ }^{29}$ In the first of two sections, I will analyze the place of visual representations in his manuscripts, dedicating much of my analysis to his early manuscripts, which amount to nearly fifty documents in total. I will start with his drawings, upon which rather a lot of ink has already been spilled, and will then widen my analysis to include other forms of visual representations: maps, tables, and diagrams. The second section looks at the finished products - Linnaeus's printed publications - and the place and role of visual representations within them.

\section{VISUAL REPRESENTATIONS IN LINNAEUS'S MANUSCRIPTS}

A first visitor to the Linnean Society is almost invariably overwhelmed by the sheer volume of material left behind by Carl Linnaeus. Apart from the numerous annotated editions of his own and others' printed works, the manuscript catalogue comprises over two hundred items-often grouping together several notebooks or fascicles tackling the same subject. They range from an undated receipt for butter in Linnaeus's hand, to the first manuscript of Species Plantarum begun in 1746 but never completed. In addition to the Linnean Society, various important manuscripts are also kept in institutions across Sweden-mostly in Uppsala and Stockholm. ${ }^{30}$

The early manuscripts reflect an important period in Linnaeus's life, when the young student first grappled with the basic concepts of botany and classification. By analyzing these early notebooks and fascicles, one gets a sense of how varied and intense these university years were for the young naturalist. Having left Växjö gymnasium in 1727, he joined Lund University where he started studying medicine. A year later, he relocated to Uppsala University.

29. My thanks to Chiara Ambrosio, who organized a session at the Third Biennial Conference of the Society for the Philosophy of Science in Practice (Exeter, July 23, 20II), which centered on the concept of representative practices.

30. A number of these manuscripts have been edited and printed: see Ewald Ährling, Carl von Linnés ungdomsskrifter, vol. I (Stockholm: P. A. Norstedt \& Söner, I888); R. E. Fries, Caroli Linnaei Hortus Uplandicus (Uppsala: n.p., I899); Malmeström and Uggla, eds., Vita Caroli Linnaei (ref. 13). 
At every stage of his student years, Linnaeus attracted the attention of influential professors, who took it upon themselves to provide lodgings and tuition to the student, giving him private lessons in botany, taking him on their botanical excursions, and allowing him access to their extensive libraries. ${ }^{31}$ Linnaeus kept notes on many topics related to natural history from a relatively young agehis first notebook, still kept in Växjö, dates from 1725. The importance of visualization is obvious throughout Linnaeus's manuscripts, but especially so in his early output. Linnaeus's early notebooks essentially record his learning process during these student years: from notes on other naturalists' classification, to catalogues of plants he collected during field trips and travels across Sweden, and finally to the tentative establishment of his own artificial system based on the sex of plants. Throughout his student years, Linnaeus learned to display information in a way that would enable him to hasten his learning and the speed with which he could commit information to memory.

\section{Drawings}

Linnaeus used drawings extensively in his early manuscripts. They range from little sketches illustrating his notes to stand-alone large-scale drawings of the fauna and flora he saw during his travels within Sweden. As mentioned above, Linnaeus has been described as a bad draftsman, and this judgment mostly stems from his Lapland diary drawings, some of which can indeed seem quite clumsy. But that is to look for a certain aesthetic merit in Linnaeus's drawings which they were not intended to have: rather the drawings, much like the maps, tables, and diagrams described below, are another kind of visual language. These drawings are often flattened: foreshortening and perspective are eschewed in preference to displaying information as plainly as possible. Linnaeus would have probably agreed with his near-contemporary Mark Catesby when the latter wrote: "Plants and other Things done in a Flat, tho' exact manner, may serve the Purpose of Natural History better in some Measure, than in a more bold and Painter like Way." ${ }^{32}$ Interestingly, it brings to mind Brian Ogilvie's remark that earlier "sixteenth-century

3r. Namely, Dr. Rothman in Växjö, Dr. Kilian Stobaeus in Lund, and Professors Olof Celsius and Olof Rudbeck in Uppsala. See Linnaeus's numerous autobiographies in Malmeström and Uggla, Vita Caroli Linnaei (ref. 13).

32. Mark Catesby, The Natural History of Carolina, Florida and the Bahama Islands, vol. I (London: Printed at the expense of the author, I73I), xi. 
[botanical] illustrations generally convey an overall impression of spreading and flattening." 33 Ogilvie distinguished two strands within early seventeenth-century botanical drawings, and it is possible to distinguish these two same functions in Linnaeus's use of drawings: naturalistic drawings, and analytical or structural drawings. ${ }^{34}$

In the case of naturalistic drawings, their main function is representational. These naturalistic drawings show that Linnaeus could draw when he wanted to and most of all when he had the time to. Many of these early naturalistic drawings are copies from printed works, as can be expected from someone who might be teaching himself to draw. ${ }^{35}$

As most young botanists of his time, Linnaeus began by studying Joseph Pitton de Tournefort's (I656-I708) precepts, which based plant classification on flower parts. The drawings of Tournefort's flowers on the flyleaves of Linnaeus's copy of Martin Johren's Vade mecum botanicum, one of the first books he acquired after starting university at Lund, are problematic (Fig. I). ${ }^{36}$ The drawings are in fact faithful copies of Christoph Bernhard Valentini's I715 Tournefortius Contractus, which was essentially a rendition of Tournefort's Rei Institutiones Herbaria (1700) in tabular and diagrammatic form, and which Linnaeus must have consulted before he had access to Tournefort's actual work. They seem so competent in comparison to a lot of drawings done by Linnaeus that Blunt refused to believe they could be his. ${ }^{37}$ Norah Gourlie, by contrast, featured them in her biography as being "original drawings made by Linnaeus." 38 The written identification of each flower part is in his hand and there is therefore no reason why the drawings should not have been undertaken by an eager and conscientious young Linnaeus.

33. Brian W. Ogilvie, "Image and Text in Natural History, I500-1700," in The Power of Images in Early Modern Science, ed. Wolfgang Lefèvre, Jürgen Renn, and Urs Schoepflin (Basel: Birkhäuser Verlag, 2003), I46.

34. Ibid., I57.

35. The precepts upheld by books such as Albert Dürer Revived (I697) to members of the elite who wished to learn to draw were to start with copies of printed works. The same was true for apprentice draftsmen: see Nickelsen, "Draughtsmen, Botanists and Nature" (ref. 4), I2.

36. Martin Johren, Vade mecum botanicum seu Hodegus Botanicus (Kolberg: Jeremiah Hartmann, I7IO), LS, BL 988.

37. Blunt, Compleat Naturalist (ref. 6), 52.

38. Norah Gourlie, The Prince of Botanists: Carl Linnaeus (London: H. F. \& G. Witherby Ltd., I953), plate 9. 


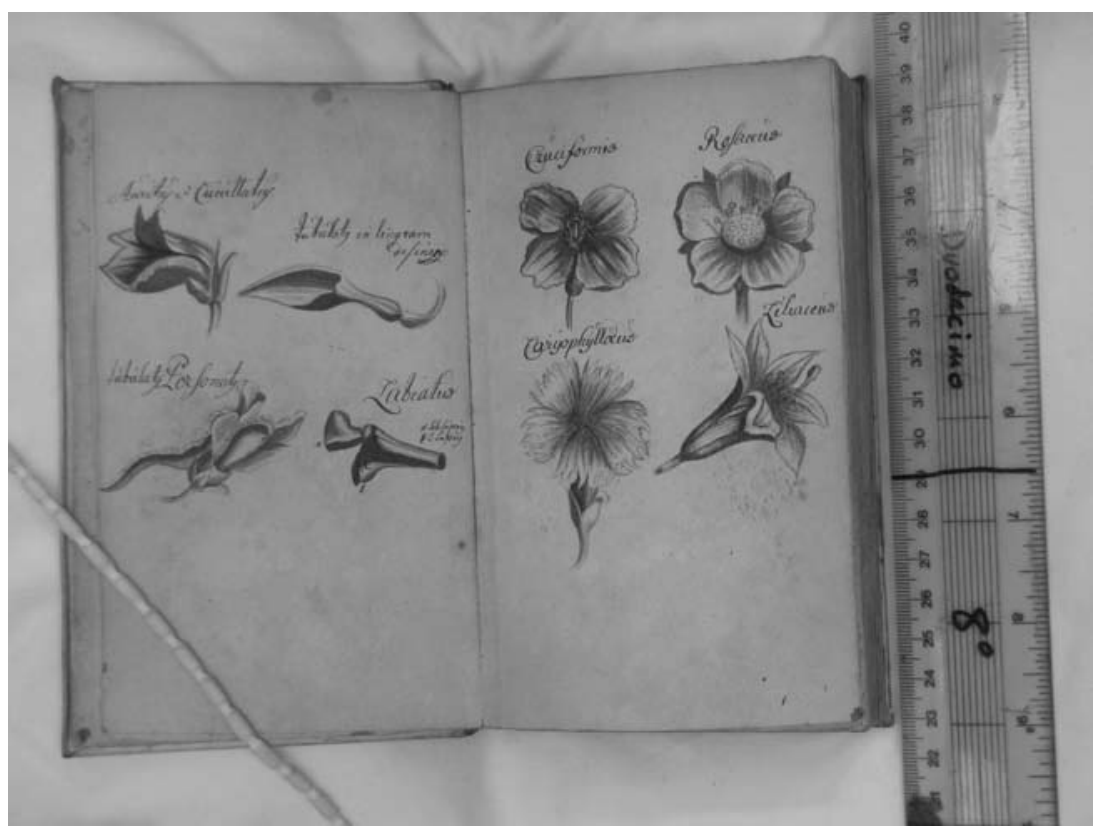

FIG. 1 Copy of Tournefort's flowers. Source: Linnaeus's copy of Johren, Vade mecum botanicum (ref. 36), bought in Uppsala in 1727. By permission of the Linnean Society of London.

The manuscript "Manuscripta Medica" (I727-I730), a notebook from his university years, also contains relatively well-rendered insects, most of them copied from Jan Jonston's De Insectis (1653). ${ }^{39}$ Sachiko Kusukawa has pointed out that "naturalistic depiction does not necessarily guarantee direct observation by the draughtsman of the object depicted." ${ }^{40}$ Indeed, the naturalistic drawings found in Linnaeus's early notebooks are almost all copies of flowers, animals, or insects that he had seen in books. The existence of a naturalistic drawing of an object by the student Linnaeus may even be taken as an indication that he had not seen the depicted object in the wild. In those cases, Linnaeus drew in order to keep a record of the encountered data.

39. Carl Linnaeus, "Manuscripta Medica," vol. I, I727-1730, LS, Box LM Gen, Folder LINN PAT GEN 2, fols. I32r.-135r.

40. Sachiko Kusukawa, "The Uses of Pictures in the Formation of Learned Knowledge: The Cases of Leonhard Fuchs and Andreas Vesalius," in Transmitting Knowledge: Words, Images, and Instruments in Early Modern Europe, ed. Sachiko Kusukawa and Ian Maclean (Oxford: Oxford University Press, 2006), 74. 
One must turn to the "Iter Lapponicum" (I732) to find naturalistic drawings clearly drawn from life and stemming from observation in the field. These demonstrate that Linnaeus was perfectly capable of drawing well, if he applied himself to do so. Some of these drawings show a concern for both structural and naturalistic qualities. The cranefly (Pedicia rivosa L., syn. Tipula rivosa L.) is a case in point: the intricate details of the wings have been extremely well rendered by Linnaeus (Fig. 2). The position of the legs

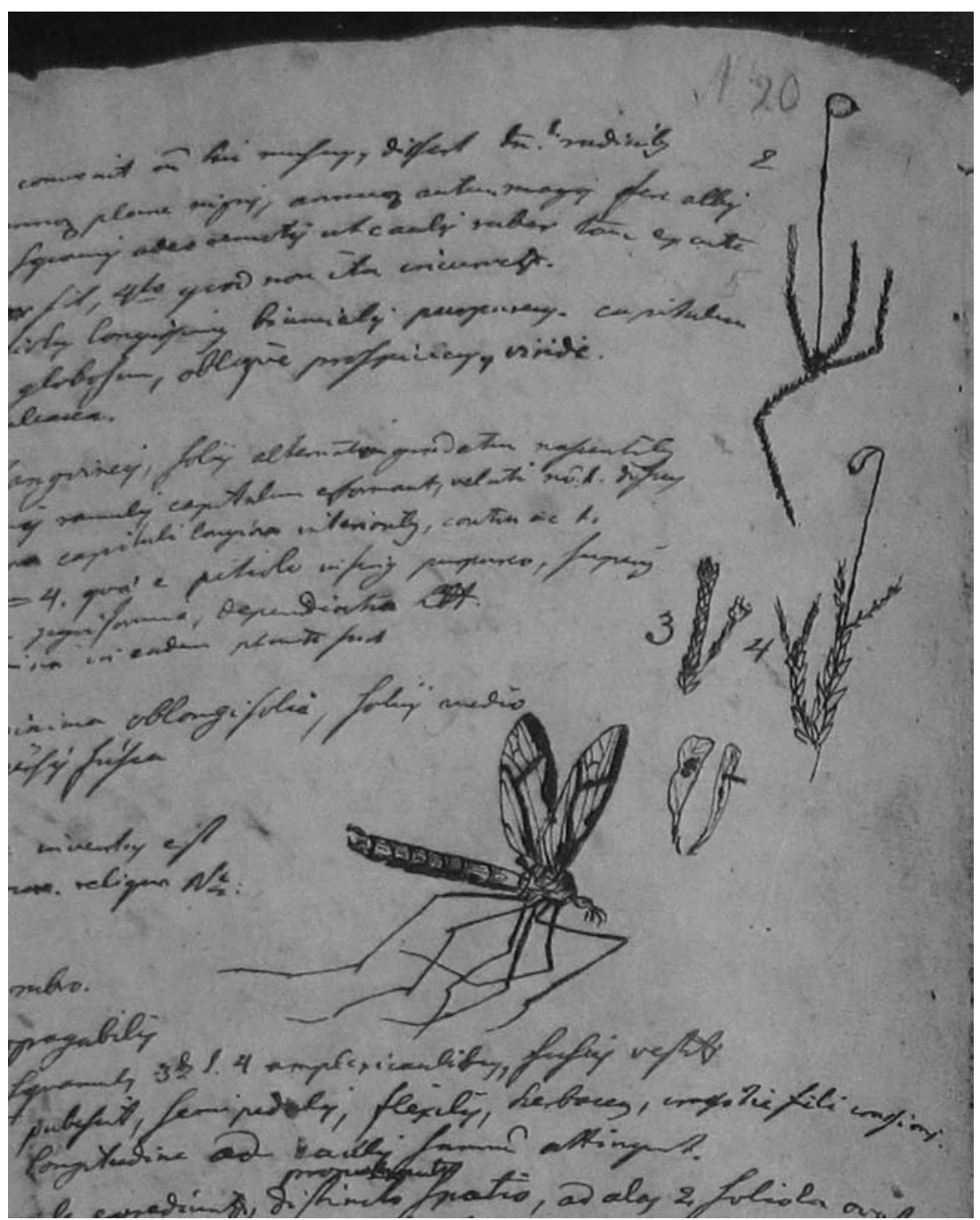

FIG. 2 Detail of the cranefly, Pedicia rivosa L. Source: Linnaeus, "Iter Lapponicum" (ref. 18), fol. 35v. By permission of the Linnean Society of London. 


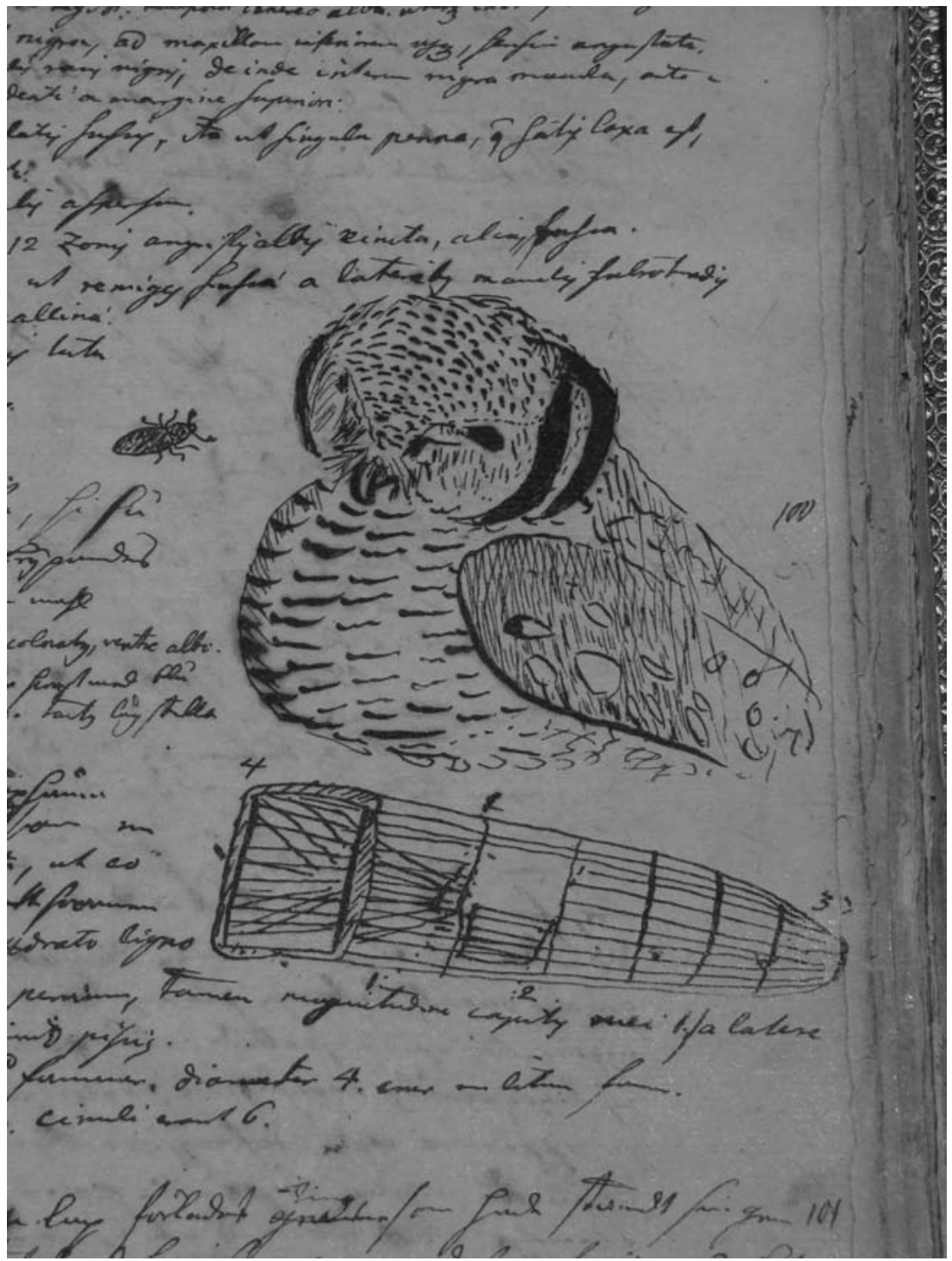

FIG. 3 Detail of an owl. Source: Linnaeus, "Iter Lapponicum" (ref. 18), fol 38r. By permission of the Linnean Society of London.

indicates that the drawing is of a dead specimen. Stearn drew particular attention to it, and qualified it as "probably the best of his sketches." ${ }^{41}$ Similarly, the drawings of an owl (fol. 38r.; Fig. 3), of a jellyfish (fol. 53r.), and of two birds 
in the papers "Oeconomia Lapponica" successfully convey the natural attitude of an animal, while also expressing its important structural details in very few strokes of the pen. ${ }^{42}$

Analytical drawings are the most common in Linnaeus's work. The emphasis is on the structure of the object depicted, and the drawing here works as an analytical and diagnostic tool. Linnaeus made most of these drawings hastily, while copying books in his mentors' libraries or making sketches in the field. What mattered was not the beauty or accuracy of the drawing but the structural information conveyed about the morphology of the plant, insect, or animal described. To this category belong the rough sketches of the flower parts from Tournefort's classification, found in Linnaeus's early "commonplace book" (1726-I727; Fig. 4). ${ }^{43}$ It is very interesting that, perhaps under the tutelage of Dr. Rothman, Linnaeus chose to arrange these rough drawings and the text describing them within a table, thereby rendering the differences between each flower efficiently visualized and recorded on a single page. Another example includes a bat in the text following John Ray's classification of quadrupeds in "Manuscripta Medica." ${ }^{44}$ The bat is depicted with wings outstretched and legs spread out (Fig. 5). Both in the written paragraph concerning the bat and in the drawing, attention is given mainly to the wings' structure. The bones articulating them are equated to the front feet ("pedes anterior"), with each finger ("digiti”) supporting the wing and described in detail, especially the top digit, or thumb ("superius") baring a sharp little claw ("ungue acuto"). By comparison, the head, body, and feet of the bat, though lively, are much more sketchily rendered.

Sketches made in "Iter Lapponicum" (I732) show the same concern for the structure of things. Linnaeus seems to have been very curious about the Sami people, their tools, and their way of life. ${ }^{45}$ What mattered to him was not so much what the tools looked like, as how they worked, and how their different parts fitted together. Therefore Linnaeus depicted

42. Carl Linnaeus, “Oeconomia Lapponica," I732, LS, Box LM Trav, Folder Oeconomia Lapponica Linnaei etc.

43. Carl Linnaeus, “Commonplace Book," I726-I727, LS, Box LM Gen, Folder LINN PAT GEN I, I84. The manuscript does not bear any title page, and the title given to it in the Linnean Society manuscript catalogue is misleading, as the notebook is not at all articulated like a commonplace book, lacking headings of any kind.

44. Linnaeus, "Manuscripta Medica" (ref. 39), fol. 83v.

45. See Lisbet Koerner, Linnaeus: Nature and Nation (Cambridge, MA: Harvard University Press, I999). 


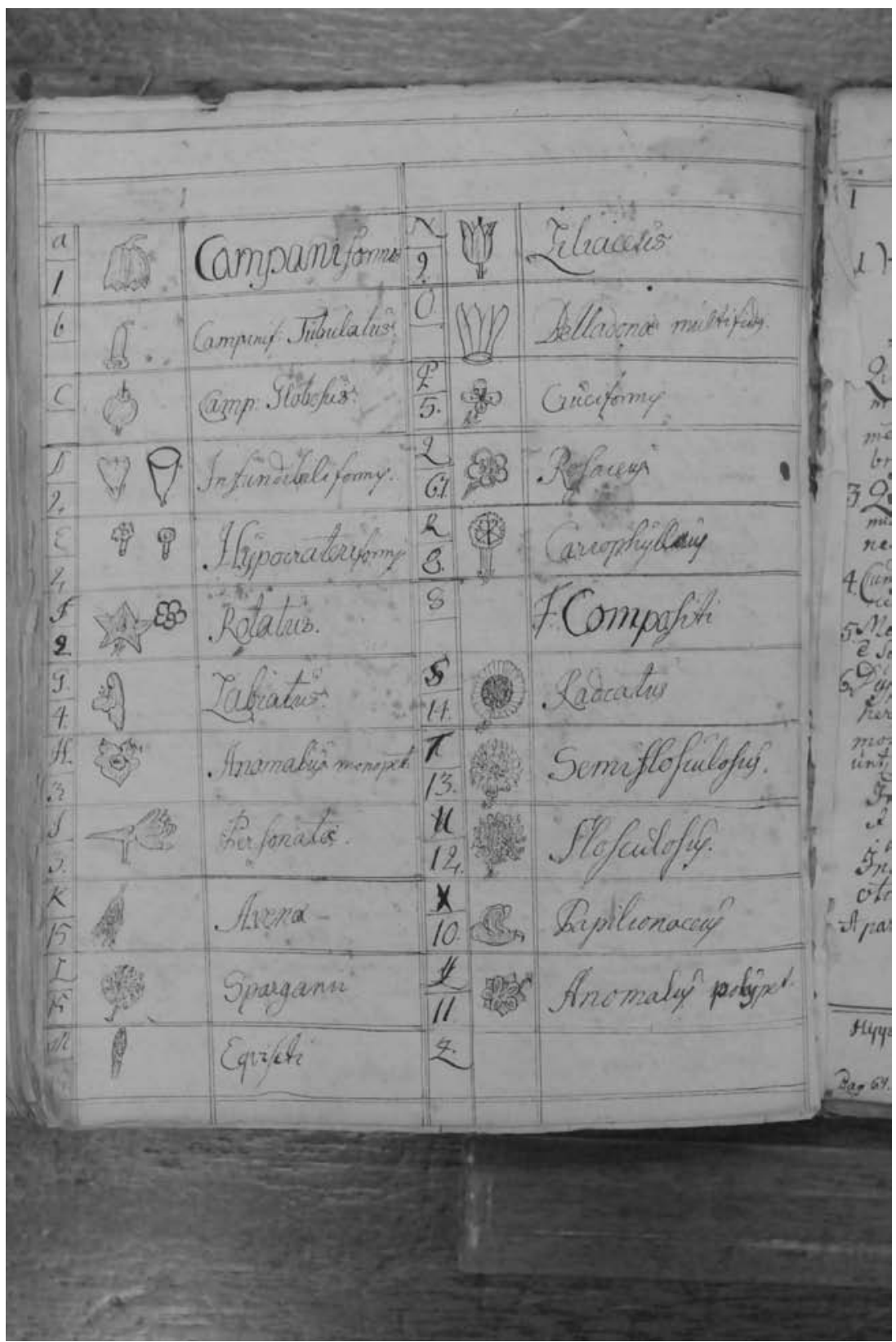

FIG. 4 Tabular arrangement of Tournefort's classification of plants. Source: Linnaeus, "Commonplace Book" (ref. 43), 184. By permission of the Linnean Society of London. 


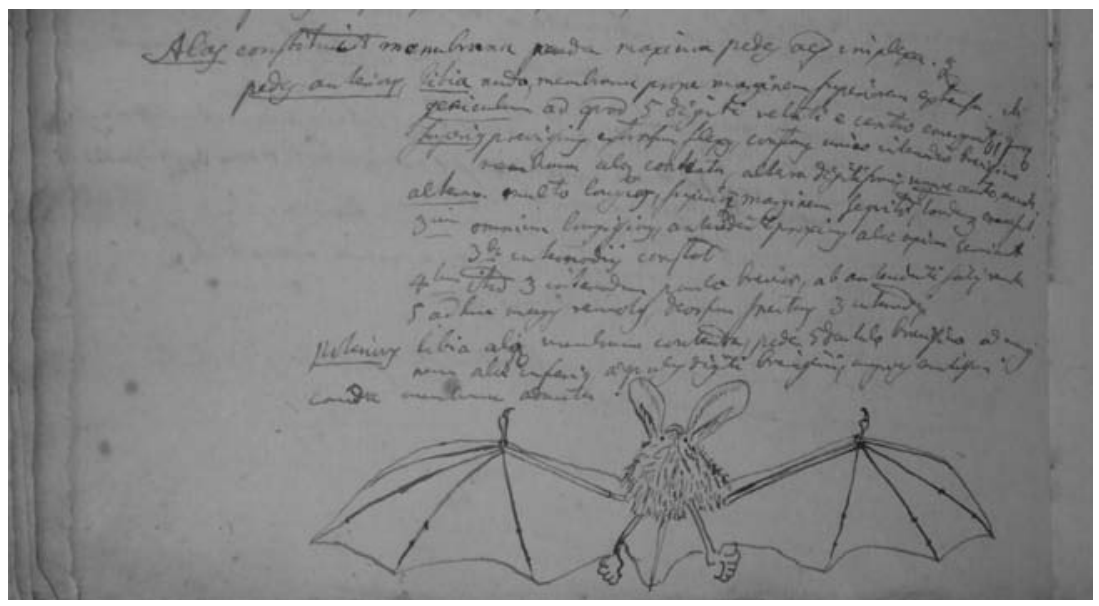

FIG. 5 Detail of a bat. Source: Linnaeus, "Manuscripta Medica" (ref. 39), fol. 83v. By permission of the Linnean Society of London.

the different components of the objects, as well as an overall view of them. This can be seen in two drawings of a canoe (fol. 25v.), for example, where the rivets and the different planks of wood are drawn in detail, indicating how the canoe was put together. A similar attention to the different pieces that make up an object is obvious in the drawing of a hoe (fol. 2Iv.). Linnaeus applied the same concern to organisms: the Lapland diary is full of drawings of plants, insects, and animals. In a list of new plant species which Linnaeus observed and collected in the field, he used sketches of the flowers as an analytical and mnemonic device (fols. 47v.-48r.). These were drawn on the spot, whereas Linnaeus usually wrote up his notes in the evening, at his camp. One has to think of the conditions in which Linnaeus was sketching during most of his Lapland journey: with no table, very little comfort, and most of the time drawing from memory what he had seen earlier during the day. Little wonder then that some of the drawings are hasty, sketchy, and sometimes downright bad.

Many drawings served exactly the same function as maps or diagrams, flattened on the page in order to convey as much information as possible in a visually striking way. When Linnaeus went to Falun in 1734 and developed an interest in mineralogy and assaying, the resulting notebooks became increasingly full of these map-like, diagrammatic drawings. The methods of assaying, the different instruments used, and the structure of the ovens are all depicted at the end of his manuscript "Vulcanus Docimasticus" (1734) in 
increasingly abstract and geographical drawings (Fig. 6). ${ }^{46}$ Each is laid out on the page in much the same way Diderot and D'Alembert set up their illustrations in the Encyclopédie, with each object depicted in isolation and then put into context in a more general illustration. For Bender and Marrinan, these illustrations are diagrammatic in essence, for they "incite a correlation of sensory data with the mental schema of lived experience that emulates the way we explore objects in the world." ${ }^{\prime 7}$ Here drawing was used very much as an analytical tool: by separating each object, Linnaeus allowed the reader to envision the various different parts of a laboratory, in order to understand the roles of different objects in the process of assaying, and the relationships linking these objects together. Linnaeus applied exactly this same analytical principle to his plant illustrations.

While I am focusing a great deal on Linnaeus's early manuscripts to show the variety and scale of the use of drawings in his early work, it needs to be stressed that Linnaeus kept on using these analytical drawings throughout his life-albeit to a lesser extent, probably because by then he had access to dried specimens. The act of drawing helped him understand the object or plant he was studying, and, as Lorraine Daston put it, to move from perception to memory and to experience. ${ }^{48}$ In the early I770s Linnaeus started using index cards to note down information on particular genera. One genus was that of Cycas, and Linnaeus hesitated for a long time with its classification, first including it with palms, and finally with ferns. ${ }^{49}$ In order to elucidate its identity and understand the structure of the plant, Linnaeus drew sketches of the leaves on one of his index cards. ${ }^{50}$

\section{Maps}

Linnaeus found maps a convenient and effective way of conveying information. He used mapping in a few of his early manuscripts and on loose sheets. He drew up a map of Professor Olof Celsius's house, with whom he stayed in Uppsala while at university during the year 1729; the map indicated the

46. Carl Linnaeus, "Vulcanus Docimasticus," vol. 2, I734, LS, Box LM Min.

47. John B. Bender and Michael Marrinan, The Culture of Diagram (Stanford, CA: Stanford University Press, 20IO), 2I.

48. Daston, "Scientific Observation" (ref. 3).

49. Today Cycas is the only genus in the cycad family Cycadaceae.

50. See Staffan Müller-Wille and Sara Scharf, "Indexing Nature: Carl Linnaeus (1707-I778) and His Fact-Gathering Strategies," Working Papers on The Nature of Evidence: How Well Do 'Facts' Travel? 36, no. 8 (2009): I-39. 


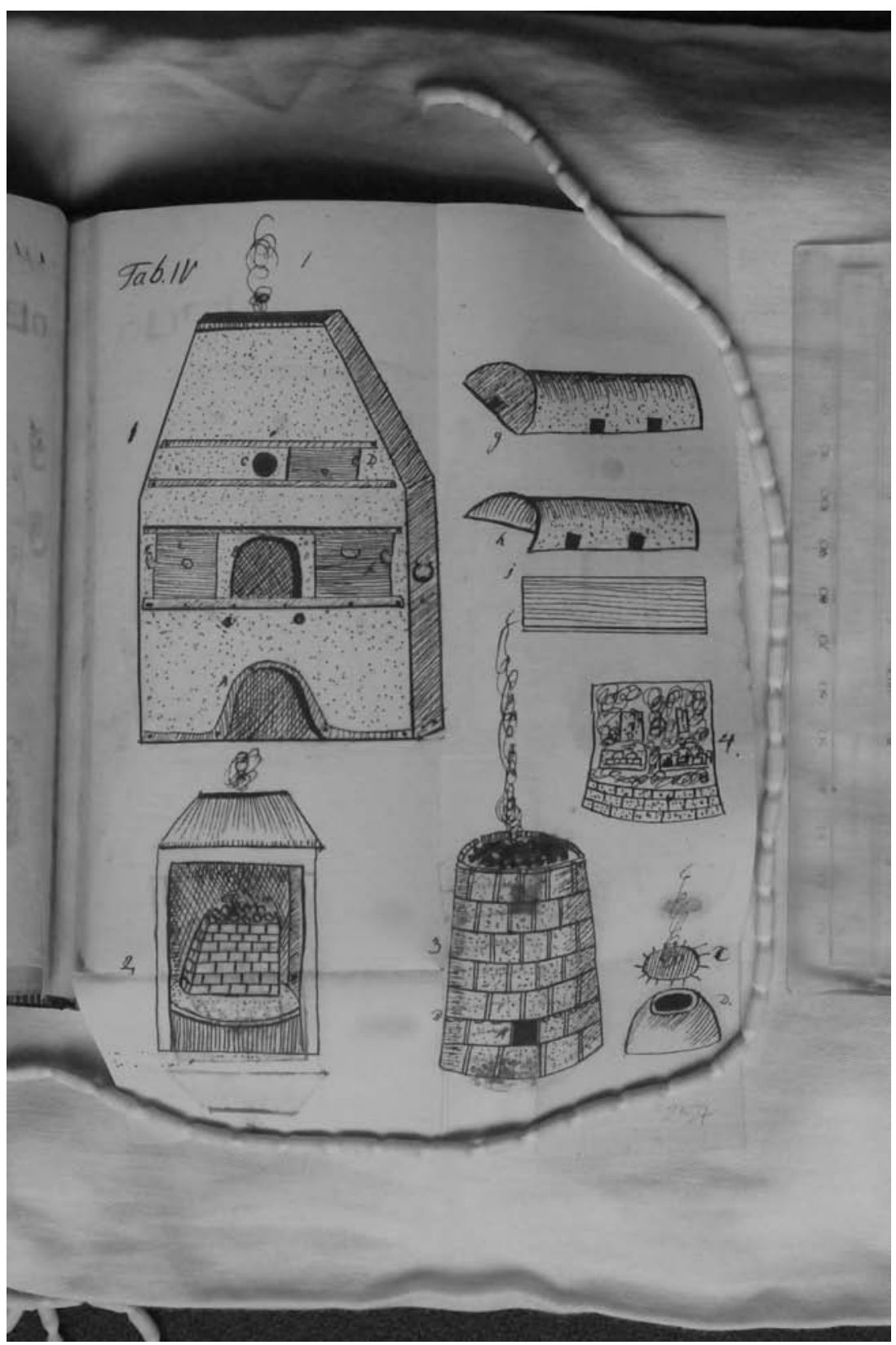

FIG. 6 Folded-out sheet at the end of the volume, depicting the process of assaying. Source: Linnaeus, "Vulcanus Docimasticus" (ref. 46). By permission of the Linnean Society of London. 


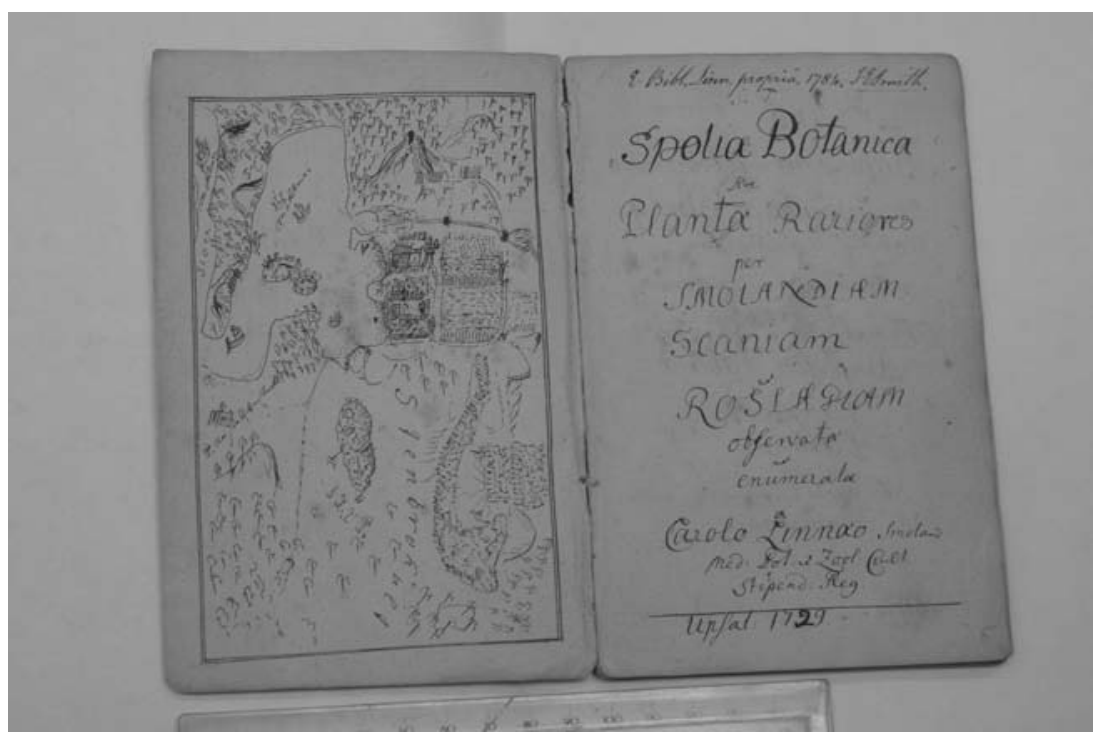

FIG. 7 Title page and flyleaf. Source: Linnaeus, "Spolia Botanica" (ref. 52). By permission of the Linnean Society of London.

positions of each person's bedroom, the larder, the kitchen, and the library. ${ }^{51}$ The flyleaf of the manuscript "Spolia Botanica" (1729) is illustrated by a map of Stenbrohult, where Linnaeus grew up and where he collected his first plants (Fig. 7). ${ }^{52}$ The map contains little drawings of boats on the lake next to the houses and of little clumps of trees to indicate vegetation. More than a map, it is a bird's-eye view of the area, a "mapped landscape," with accurate renderings of specific landmarks. ${ }^{53}$

In most of Linnaeus's visual representations of landscapes, the boundary between drawing and map-making is relatively loose. In the Lapland travel papers are several drawings of Lapland landscapes in which the same elements always figure: the midnight sun, a little figure carrying a boat in portage style, rolling hills, and mountains. ${ }^{54}$ These landscape drawings, which can appear quite naïve or awkward, act as geomorphological and anthropological maps of the region. One of these representations (Fig. 8), which contains a title, was a design for the frontispiece of a book, some elements of which were later

5I. Carl Linnaeus, "Plan of Celsius House," n.d., LS, Box LM Bio, Folder Plan of a House.

52. Carl Linnaeus, "Spolia Botanica," I729, LS, Box LM Bot, Folder Spolia Botanica.

53. Svetlana Alpers, The Art of Describing: Dutch Art in the Seventeenth Century (London: John Murray, 1983), I42.

54. Linnaeus, “Iter Lapponicum” (ref. I8), fol. 46r.; Linnaeus, “Oeconomia Lapponica” (ref. 42). 


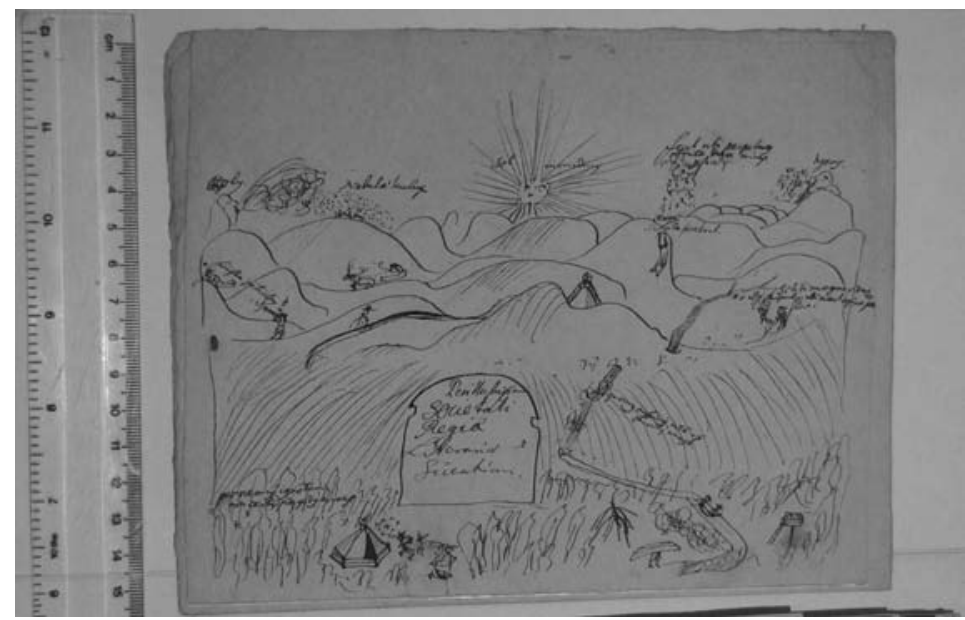

FIG. 8 Lapland landscape. Source: Linnaeus, "Oeconomia Lapponica" (ref. 42). By permission of the Linnean Society of London.

used in the frontispiece for Flora Lapponica (1737). Linnaeus indicated what he was representing with the help of words: hence the little face blowing wind is "Eolus"; a little figure falls to his death with the comment "thus fate carries him off" ("sic illum fata ferebant"). Most of the little actions figured relate to incidents that happened to Linnaeus in his Lapland travel. In this case, the information conveyed by a map alone was not sufficient: drawings and words combine to make the reader understand the dangers and tribulations which Linnaeus experienced as a traveler to Lapland. Like the map of Celsius's lodgings, this drawing also shows the importance of Linnaeus locating himself within these maps.

In all of these cases, the functions and attributes of maps and drawings are very much conflated. Linnaeus's blended use of maps and drawings recalls the "coincidence between mapping and picturing" that Svetlana Alpers has described in seventeenth-century Dutch art. For her, such a coincidence emerged from a "common notion of knowledge and the belief that it is to be gained and asserted through pictures." 55 Cartographers and painters were both representing the world on a two-dimensional surface. Art figured in maps, and maps in paintings. In Dutch art, the distinction between the two forms is particularly fluid. This same fluidity is found between various 
modes of representations in Linnaeus, and it corresponds to a contemporary overlapping understanding of these representations. The distinction between pictures and maps was not as clear-cut as it is today, a map being understood and seen as a kind of picture. ${ }^{56}$ Alpers further points out that one of the common terms to describe mapping was descriptio, and while her concern is to link such a concept to painting, the use of such a term is of course hugely determinant for early modern naturalists. In many ways, the aims of a cartographer and of a naturalist were similar: "to capture on a surface a great range of knowledge and information about the world." 57 Most naturalists of the period also engaged in activities of exploration, which, in addition to collecting and describing animals and plants, also consisted of recording new territories and boundaries through map-making. ${ }^{58}$ In French Guyana, for example, both Charles Marie de La Condamine, member of the Académie des Sciences of Paris, and Jacques-François Artur endeavored to collect as many observations and specimens of the natural world around them as possible, while at the same time mounting expeditions to map the Amazon river and to determine the longitude of Cayenne. ${ }^{59}$ It is unsurprising therefore that mapping should be of central importance to Linnaeus's enterprise, as one of many representative practices to which he had recourse in order to display, memorize, and reflect upon his and others' knowledge of the natural world. By mapping out the information of the natural world, Linnaeus could better apprehend the known species, while such maps also showed the undiscovered territories, where research had yet to be carried out.

\section{Diagrams and Tables}

Dichotomous diagrams were the "famous feature of Ramist method." ${ }^{60}$ As Hotson has shown, "their systematic use offered students quick and easily understood outlines of complex subjects," and it is exactly in this way that

56. Ibid., I26.

57. Ibid., I22.

58. Daniel R. Headrick, When Information Came of Age: Technologies of Knowledge in the Age of Reason and Revolution, 1700-1850 (Oxford: Oxford University Press, 2000). See chap. 4: "Displaying Information: Maps and Graphs."

59. Céline Ronsseray, "Jacques-François Artur: Médecin du roi et historien en Guyane française au XVIIIle siècle," in Explorations et voyages scientifiques de l'Antiquité à nos jours, ed. Christiane Demeulenaere-Douyère (Paris: Editions du CTHS, 2008), 6I-62.

6o. Hotson, Commonplace Learning (ref. 2I), 46. 
Linnaeus used them, especially during his student years. ${ }^{61}$ Dichotomous diagrams, representing divisions of contradictory parts, were regularly used to convey classifications of the natural world throughout the early modern period. Designed to be read from left to right in a logical chain of ideas, the dichotomous diagram differs from a table, which can be read in any direction. Like the map, it was used by Linnaeus as both a mnemonic and a cognitive tool. The young naturalist started copying dichotomous diagrams from medical texts: his first notebook, the "Örtabok" (I725) includes two such diagrams, one describing the main types of illness and the other concerning purgatives that are copied directly from Georg Wolfgang Wedel's Theoremata Medica (1677). Linnaeus then appropriated the dichotomous diagram as a means of displaying other naturalists' classifications. As he wrote in Genera Plantarum, the artifical character "is the easiest for the intellect, and it is provided in dichotomous or synoptic tables." ${ }^{\text {"62 }}$ Linnaeus used it especially to convey his reading of a work, in a way that made it easy for him to visualize at a glance the classification used by the naturalist he was copying. These diagrams often came before more detailed notes of particular species or genera. Most of the diagrams are found in "Manuscripta Medica," which contains fourteen such diagrams: they convey the botanical works of Tournefort (from Valentini), Augustus Quirinus Rivinus (from Johann Heinreich von Heucher), Johan Jacob Dillenius, John Ray, as well as Ray's works on quadrupeds and birds, Jan Jonston's and Martin Lister's works on insects, Lister's work on shells, and an unattributed diagram on bloodless animals. ${ }^{63}$

Linnaeus clearly used diagrams as a thinking tool, and often changed or adapted the information he found in the works he copied from. These diagrams never exceed two pages, and whenever possible they are on a doublepage spread, enabling Linnaeus once more to contain the information in a restricted paper space, and to limit it to a manageable length. The layout of the diagrams - whereby in some cases the writing becomes more tightly packed towards the lower end of the page-and various crossings out suggest that Linnaeus did not draw up rough drafts before committing them to paper. This in turn might suggest that he would have read the entire book before organizing it into a diagram. In this practice, he was following John Locke's advice, who wrote on the art of note-taking in his A New Method of

6I. Ibid.

62. Müller-Wille and Reeds, "Introduction to Genera Plantarum" (ref. 2), 578.

63. Linnaeus, "Manuscripta Medica" (ref. 39). 
Commonplace Book, to always read a book twice, and only take notes of it in a commonplace book at the second reading-although it needs to be stressed that there is no evidence that Linnaeus ever read Locke. ${ }^{64}$

One example will suffice to show how Linnaeus drew up his diagrams. The diagram summarizing Ray's Synopsis Methodica Avium (1713) is a good example of Linnaeus's reading of a particular work (Figs. 9a and b). ${ }^{65}$ Linnaeus managed to render obvious and straightforward a work whose organization can seem confusing, and to make its classification stand out. In order to simplify and make Ray's contents more concise-and to make them easier to remember-Linnaeus systematically eliminated all the exotic species, focusing rather on the familiar as representative of its class. From Ray's long taxonomic appellations, Linnaeus only retained a word or two. There is a concern for conciseness in the vocabulary used, and an emphasis on the relevant differences. Linnaeus also did not tend to copy all the genera listed by Ray, but only one or two-generally the better known. For the birds of prey, for example, Linnaeus selected Falco (falcon), Milvus (kite), and Accipiter (hawk), leaving aside Subbuteo (hobby) and Lanius (shrike), among others.

Much like the representative practices seen previously, the diagrams reflect Linnaeus's learning and training in botany and other branches of natural history. They show what Linnaeus deemed important, what he retained, and what he was willing to skip or discard. They also show that visualizationthrough diagrams as well as drawings, maps, and tables-was an important first step in Linnaeus's learning and memorizing process.

One of the first tables drawn up by Linnaeus was that which has been described earlier, a copy of Tournefort's classification of plants, based on flower parts, arranged in a table contained on one page (Fig. 4). ${ }^{66}$ From very early on, Linnaeus learned to take notes efficiently, accompanied by drawings, but also to display this information in a way that made it easy to display and memorize, here with the use of a table. In order to better memorize Tournefort's twentythree classes, Linnaeus labeled each of the rows according to letters of the alphabet (omitting our $j$ and $w$, and leaving the last letter $z$ empty)—which is how he would later arrange his own sexual system. In addition, he indicated the page number from Valentini's Tournefortius Contractus (I7I5). For some

64. John Locke, A New Method of Making Common-Place Books (London: John Greenwood, I706), v.

65. Linnaeus, "Manuscripta Medica" (ref. 39), fols. 82, 86.

66. Linnaeus, "Commonplace Book" (ref. 43), I84. 
388 | CHARMANTIER
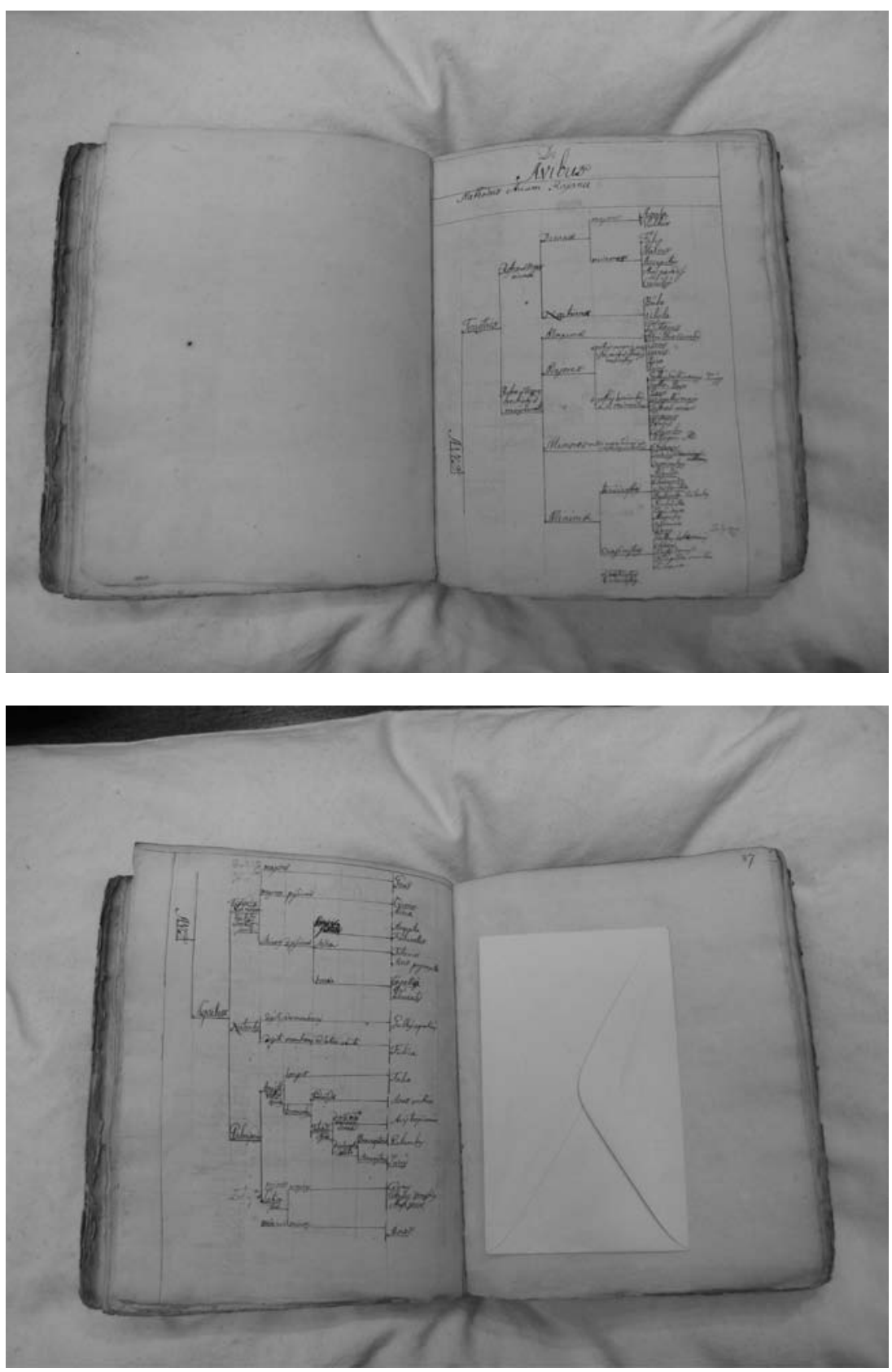

FIGS. 9A AND B Dichotomous diagram showing Ray's classification of birds. Source: Linnaeus, "Manuscripta Medica" (ref. 39), fol. 86. By permission of the Linnean Society of London. 


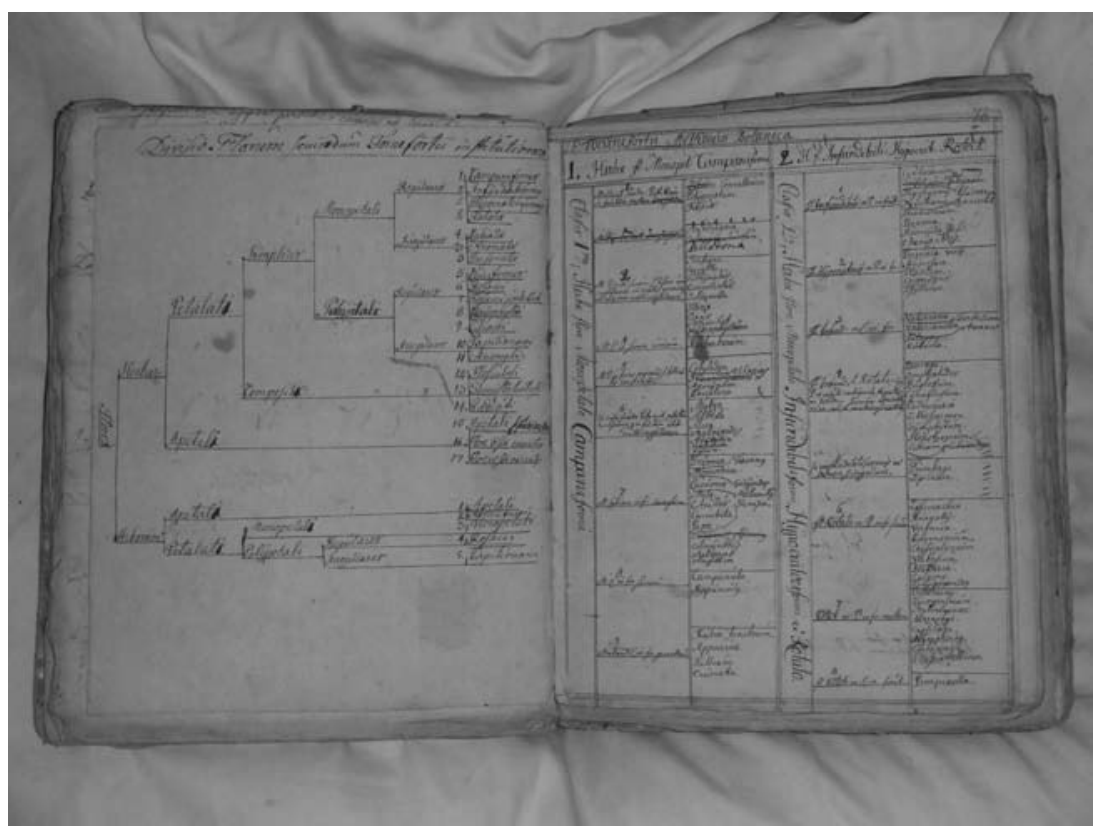

FIG. 10 Dichotomous diagram and table detailing Tournefort's classification of plants. Source: Linnaeus, "Manuscripta Medica" (ref. 39), fols. 9v-10r. By permission of the Linnean Society of London.

reason, Linnaeus did not follow Valentini's order, which is why he then needed to refer to the relevant page numbers. Looking at this table required very little cognitive effort, and associated letter of the alphabet to rough drawing and name of the corresponding class. This visual display must have allowed Linnaeus to very quickly memorize Tournefort's essential classificatory principles.

Linnaeus returned to Tournefort's system at the very beginning of "Manuscripta Medica." This time, he went into much more detail in representing Tournefort's classification of plants, taking up five folios of the first volume of "Manuscripta Medica" and allying a dichotomous diagram to a table (Fig. Io). ${ }^{67}$ The main classes of Tournefort are outlined in the diagram, and the details of orders and genera are delved into with the help of a table. Again, Linnaeus's structure of the classification (diagram with table) was probably inspired by Valentini's work. ${ }^{68}$ Nevertheless, by then Linnaeus must have had access to Tournefort's actual work, since he included several genera which

67. Linnaeus, "Manuscripta Medica" (ref. 39), fols. 9v-I4v.

68. Linnaeus mentions using Valentini's work in one of his autobiographies. See Malmeström and Uggla, eds., Vita Caroli Linnaei (ref. I3), Vita III, 92. 
were not in Valentini but featured in Tournefort's appendix-these are for example Tamariscus, Tamarindus, Papaya, and Sapindus (all on folio I4v.). Therefore Linnaeus, while inspired by Valentini's way of displaying Tournefort's classification, once again did not simply copy it but drew a table from scratch, based on his own reading of Tournefort.

The act of drawing a diagram or a table was itself part of Linnaeus's self-teaching program. Linnaeus not only reproduced it but adapted it and made some modifications to it at different times (as is apparent from the occurrence of different ink colors). The alliance of a diagram and a table prefigured the way he displayed information in his Systema Naturae in 1735, and which he likened to a geographical map: a diagram for the main tenets — the key—and a table going into more details. Linnaeus arranged the information in such a way that each class is always contained within one page, which allowed him to save on paper, but also to ensure that one never had to turn the page for more information. In effect, the page acts as a kind of box: the table is a contained whole, enclosed by lines and filled with boxes within boxes at every level: class, order, and finally genus. In this particular case, the last box is that containing genera. The manuscripts show that this system of drawing lines on paper to form boxes in which to contain and drop either genera or species was adopted from very early on, and Linnaeus would continue it for his own classificatory purposes throughout his career and in much later manuscripts and printed works. This method would highly influence his way of thinking about genera and their role in a natural order. ${ }^{69}$

In 1730 and 173I Linnaeus produced a series of manuscripts cataloguing the plants around Uppsala and in the Uppsala botanical garden. These manuscripts were primarily used for teaching purposes. The visual tools, initially inherited from the pedagogical commonplacing tradition and which he idiosyncratically developed to explore the natural world, became in turn part of his teaching methods. While the first two catalogues are classified according to Tournefort, the last three represent Linnaeus's first attempts at a classification according to his own sexual system. The last of these manuscripts, "Adonis Uplandicus" (I73I), is interesting because it is in some ways the end product of the author's years of learning how to display information on a page. ${ }^{70}$ In "Adonis,"

69. See Staffan Müller-Wille, "Collection and Collation: Theory and Practice of Linnaean Botany," Studies in History and Philosophy of Science Part C: Studies in History and Philosophy of Biological and Biomedical Sciences 38, no. 3 (2007): 54I-62; Müller-Wille and Scharf, "Indexing Nature" (ref. 50).

70. Carl Linnaeus, "Adonis Uplandicus," 173I, Uppsala University Library, Leufsta Ms. 
Linnaeus used several of the visual representational tools with which he had been practicing for several years: map, table, dichotomous diagram and drawing (Figs. Ira and b). On the flyleaf opposite the title page, Linnaeus drew an intricate map of the Uppsala botanical garden, detailing the flower beds, and, in the bottom left corner of the map, the pond filled with four large fish

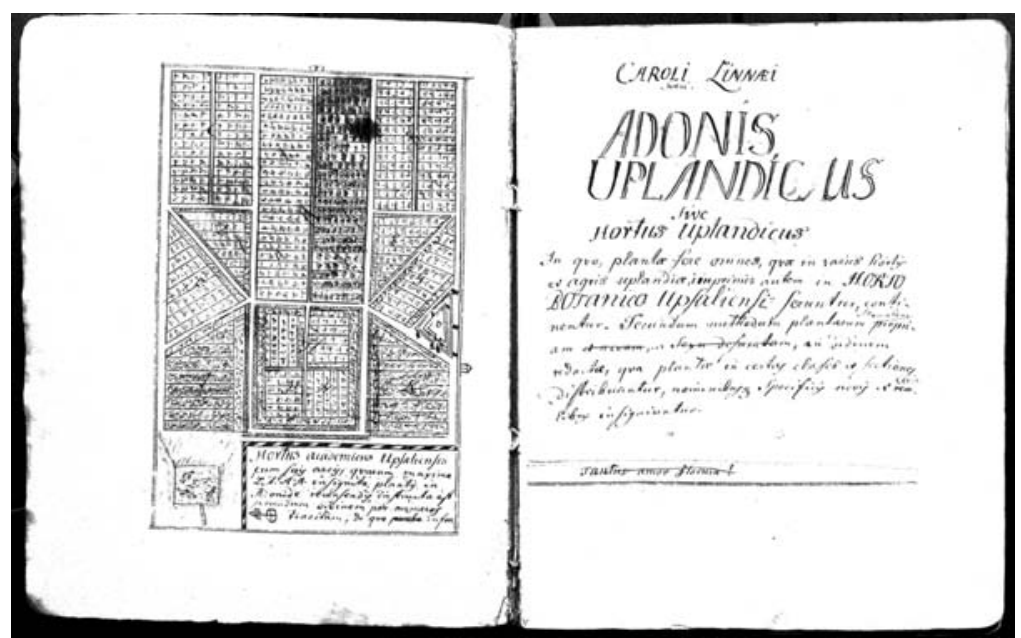

FIG. 11A Flyleaf and title page. Source: Linnaeus, "Adonis Uplandicus" (ref. 70). Courtesy of Uppsala University Library, photo (c) Uppsala University Library.

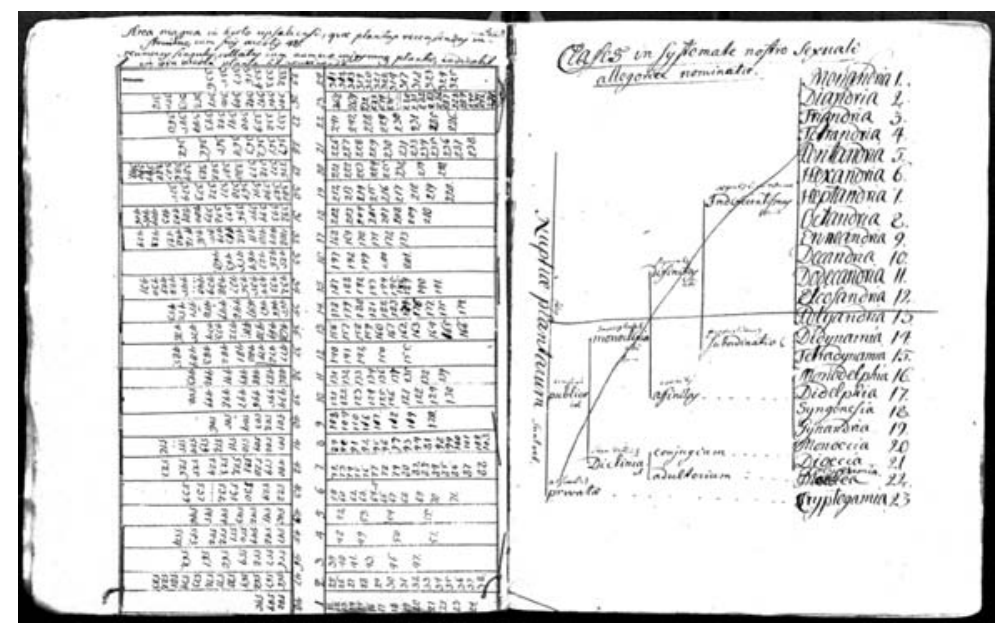

FIG. 11B Map of the flower bed arranged according to the sexual system, and dichotomous diagram detailing the sexual system. Source: Linnaeus, "Adonis Uplandicus" (ref. 70), 8-9. Courtesy of Uppsala University Library, photo (c) Uppsala University Library. 
and the stream feeding into the pond. The facing title page is elaborately designed like that of a printed book. Situated a little further into the manuscript, on page 9, a diagram indicates the overview of his classification: the twenty-three (later to become twenty-four) classes of the sexual system. Facing the diagram is what looks like a table, with horizontal rows of numbers in two columns. This table is in fact a map of two flower beds, the numbers corresponding to the numbers attributed to genera within the work. This table/map corresponds to the two upper center flower beds within the bigger map on the flyleaf. Here then are several modes of representation which are intricately linked by the information they convey: one leads to another, and the boundaries between table and map break down. Where maps have always represented the mapped terrain, what Linnaeus effected, albeit on a modest scale with his flower bed, was a situation where the table predetermined and created the terrain.

\section{VISUAL REPRESENTATIONS IN LINNAEUS'S PRINTED OUTPUT}

Clear-cut visual representations are notably absent from Linnaeus's major publications such as Genera Plantarum (1737), Classes Plantarum (1738), and Species Plantarum (1753). Such works tried to establish taxonomic and morphological relations between genera or between species, which cannot easily be shown using drawings. There are reasons - both practical and philosophical-why Linnaeus's major works lack any sort of visual representations. One practical reason for excluding illustrations was to minimize their publication costs, and to ensure that the printed works could be made available at prices that were not prohibitively expensive. As Heller has shown, Linnaeus protested against the astronomical cost of lavishly illustrated botanical books in his Incrementa Botanices (1753): the "use [of figures], however, has so increased the price of the books that not a few Sons of Botany who are reared in modest circumstances are compelled to do without such high-priced books." 71 Linnaeus deplored that such books were not making botany accessible to students with limited means, as he himself had once been. Moreover, most of his major classificatory works were simply too big to contain illustrations: the first edition of Species Plantarum (1753) was a twelve-hundred-page, two-volume work. It was too enormous a project to ever consider supplementing with illustrations. 
Other forms of visual representation, nevertheless, can be found in numerous Linnaean publications, and resurface even in these main classificatory works which seem not to rely on illustrations. These visual techniques echo the ones Linnaeus successfully established in his manuscripts, and thus testify to the reciprocity between manuscript and printed sources. Having practiced with these representations as a student, and integrated them in his own day-to-day research process, Linnaeus applied them to his printed works.

\section{Drawings}

As referred to in the passage from Genera Plantarum quoted at the beginning, Linnaeus believed a genus could not be accurately represented by a single drawing. Whereas this passage has been interpreted as a general criticism of drawing, it is drawings of genera that Linnaeus specifically addressed. For him, illustrating a genus was impossible to achieve, for it ignored the full spectrum of different species contained in any particular genus. Whereas a drawing would have to take into account all the differences expressed in different species, a written description of a genus only had to describe the common features shared by these species:

If in one and the same genus, as in most genera, parts differ by number and shape among distinct species, I would nevertheless be obliged to note the situation and proportion of the parts. I cannot express this in any way in a drawing unless I give as many figures. Therefore, if there were 50 species, and just as many different ones, I would have to deliver just as many pictures. Who would be able to extract any certainty from such a multitude? But to omit the differing parts from a description and to describe those agreeing is a much easier task, and easiest for the intellect. ${ }^{72}$

Linnaeus was therefore not averse to images and drawings per se, but found them unhelpful in descriptions of genera. Conversely, he advocated the use of illustration in the context of species, and gave precise instructions to follow in Philosophia Botanica (I75I). There, he instructed that "the best pictures should show all the parts of the plants, even the smallest parts of the fruitbody. The most numerous and outstanding differences, which do most to distinguish a species, lurk in the smallest parts. ${ }^{, 73}$ Further on, he insisted on the

72. Müller-Wille and Reeds, "Introduction to Genera Plantarum" (ref. 2), 568.

73. Carl Linnaeus, Philosophia Botanica, trans. Stephen Freer (Oxford: Oxford University Press, 2003), 284. 
importance of drawing rare species when a botanist is traveling: "The rare [plants] should be described, drawn and colored." 74

Drawings are therefore not entirely absent from Linnaeus's printed works and can be found in a variety of published works, from his first publication in 1735 to his later dissertations. Linnaeus was aware of botanists who could draw, and he praised them in Philosophia Botanica: "The botanists that have also practised the arts of drawing and engraving have left the most outstanding figures." 75 However, much like most of the famous botanists, Linnaeus did not draw himself, but had artists draw for him. The importance of these craftsmen and artisans in the development of natural history has been highlighted in recent years by historians. ${ }^{76}$ With the exception of Dillenius, who illustrated his own works, botanists usually turned to artists in order to illustrate their works: John Ray and Francis Willughby traveled Europe collecting plates by various local artists; ${ }^{77}$ Martin Lister employed English artists William Lodge and Francis Place for his Historiae Animalum Angliae (1678); ${ }^{78}$ Tournefort entrusted the drawings and engravings for his Elémens de Botanique (1694) and for his Institutiones Rei Herbariae (I700) to the artist Claude Aubriet, who later also made drawings for Sébastien Vaillant's Botanicon Parisiense (1727). ${ }^{79}$

Linnaeus's first seminal work, Systema Naturae, published in 1735 in Leiden, aimed to classify the whole of the natural world through a series of large-scale tables. It was accompanied by a plate depicting the twenty-four classes of the sexual system (Fig. I2). This now famous illustration had been drawn in 1736 by the botanical artist Georg Dionysius Ehret, who met Linnaeus when the latter was working for Georg Clifford in Holland, and who also illustrated the catalogue drawn up by Linnaeus of Clifford's garden, Hortus Cliffortianus (1737). "Linnaeus and I were the best of friends," Ehret wrote, "he showed me his new method of examining the stamens, which I easily understood, and privately resolved to bring out a Tabella of it. . . . With this Tabella I earned some money; for I sold it at 2 Dutch gulden

74. Ibid., 332.

75. Ibid., 284 .

76. Smith, "Art, Science, and Visual Culture" (ref. 3).

77. Charles Raven, John Ray: Naturalist_His Life and Works (Cambridge: Cambridge University Press, 1942), 313.

78. Robert Urwin, "A Provincial Man of Science at Work: Martin Lister, F. R. S. and His Illustrators, I670-1683," Notes and Records of the Royal Society 49, no. 2 (1995): 209-30.

79. Blunt, Art of Botanical Illustration (ref. 17), II3-15. See also Nickelsen, "Draughtsmen, Botanists and Nature" (ref. 4), Io. 


\section{Clarisf: L.IN N E I. M. D.}

ME'THODUS plantarum $S$ EXXALIS

in $S$ ISTEMATE NATURE

defcripta

$\sqrt{3}$

A
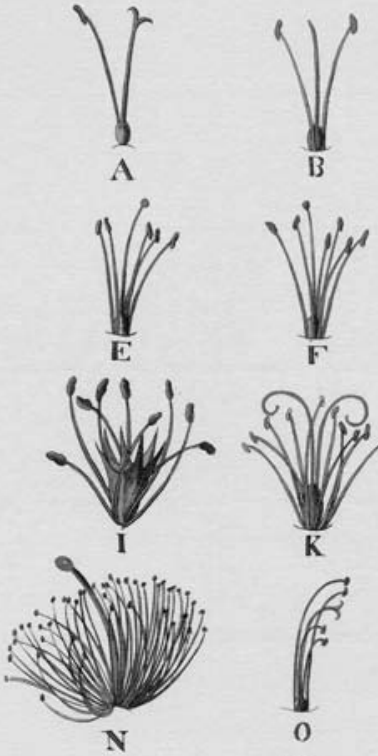

F
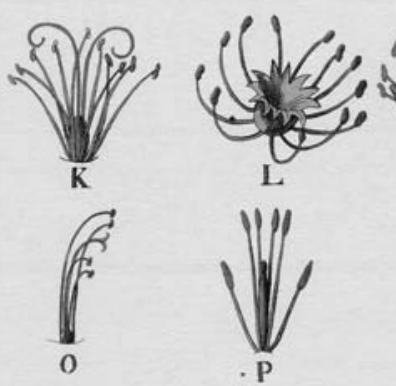

L
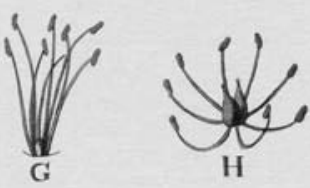

$\mathrm{H}$

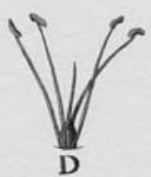

D

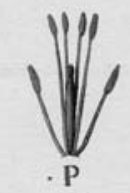

$\mathrm{M}$

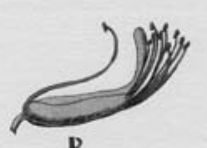

$\mathbf{R}$
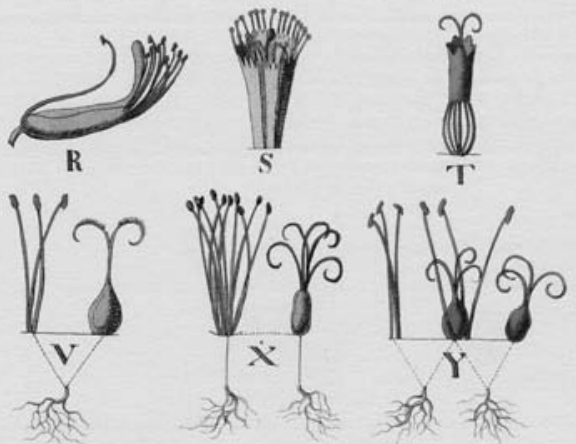

G.D.EHRE'T. Palat theidelb:

Luggd. bat: $: 1736$

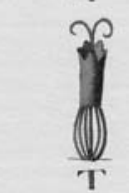

fecit $x$ edidit

FIG. 12 Georg Dionysius Ehret, "Methodus Plantarum Sexualis in Sistemate Naturae Descripta" (Leiden, 1736). The twenty-four classes of Linnaeus's sexual system. By permission of the Linnean Society of London. 
apiece, and almost all the botanists of Holland bought it of me." ${ }^{80}$ Linnaeus reproduced it, without acknowledging Ehret, in all subsequent editions of both Systema Naturae and Genera Plantarum. Later editions of the Systema Naturae also contained eight plates at the back of the volume: a plate of quadrupeds' crania, and others of birds, amphibians, fish, insects, worms, plants, and minerals. These plates were designed to help the reader distinguish the main characters of each class of animal, plant, or mineral. The plate for birds, for example, concentrated on the different aspects of the bills, feet, and wings.

Similarly, Philosophia Botanica (I75I) contained eleven plates at the end, which were meant to help readers identify the main parts of the plants and familiarize themselves with the appropriate vocabulary. The last plate illustrates how to build one's own herbarium. ${ }^{81}$

Drawings and figures can also be found in monographs depicting specific plant species. One early example is Musa Cliffortiana (1736), where Linnaeus included a picture of the flowering banana tree that he had observed in Clifford's garden in Holland along with a detailed illustration of its fruit. ${ }^{82}$ Most of Linnaeus's published monographs took the form of one of his students' numerous dissertations, the majority of which were for the most part written by Linnaeus, but defended orally by the students. ${ }^{83}$ A number of these dissertations concentrated on specific species of plants and were sometimes illustrated by one or two plates. Of the I86 Linnaean dissertations, forty-four include figures, and the majority of those correspond to dissertations concerning specific plant species. The 1744 De Peloria, defended by the student Daniel Rudberg (who never actually saw the plant), contains an illustration of the "monster" plant (Fig. 13). ${ }^{84}$ Engraved on a slightly larger

80. Quoted in Blunt, Art of Botanical Illustration (ref. 17), I45.

8I. Staffan Müller-Wille, "Linnaeus' Herbarium Cabinet: A Piece of Furniture and Its Function," Endeavour 30, no. 2 (2006): 60-64.

82. The draftsman for the two plates in Musa Cliffortiana was Martinus Hoffman and the engraver was Adolf van der Laan. The wealth of its production-a result of George Cliffort's patronage-makes it an exception in Linnaeus's output. See Carl Linnaeus, Musa Cliffortiana: Clifford's Banana Plant, ed. Tod F. Stuessy and Franz Stadler, trans. Stephen Freer, vol. I48, Regnum Vegetabile (Vienna: International Association for Plant Taxonomy, 2007); Staffan Müller-Wille, "Introduction," 24-25.

83. John Lewis Heller, "Notes on the Titulature of Linnaean Dissertations," Taxon 32 (1983): 218-52; Stearn, Linnaeus: Species Plantarum, vol. I (ref. 7), 52-64. Stearn has a list of all the published dissertations.

84. Carl Linnaeus, De Peloria (Uppsala: 1744). See Åke Gustafsson, "Linnaeus's Peloria: The History of a Monster," Theoretical and Applied Genetics 54 (I979): 24I-48. 
page that unfolds from the rest of the work, the flowering plant is depicted in all its length from root to flower, while four smaller figures give various views of one of the flowers in its real scale (magnitudine naturali): from above, from below, in profile, and in cross-section to show pistils and stamens. Finally, emerging from the left-hand side of the page, the drawing of a hand proffers the flower of another species ("Antirrhinum") in order to emphasize the differences between the two. The analytic function of such an illustration is obvious-it conveys all there is to know about the various different parts of the plant in one illustration, using several figures and elements of comparison.

\section{Maps}

Linnaeus owned many maps: he used and drew them up for his travels, and he was sent maps by his correspondents as gifts. In 1748, for example, Linnaeus was sent three maps of Venice from Joseph von Rathgeb, ${ }^{85}$ and Johann Georg Gmelin promised to send him a better map of Russia. ${ }^{86}$

Although maps as such were rarely if ever used in his published output, mapping and geographical metaphors permeate Linnaeus's printed works. The recurrence of the map metaphor to represent Linnaeus's classificatory systems is easily understood in the light of Linnaeus's early reliance on the medium, as discussed above. When it was published in 1735 , Linnaeus and his contemporaries repeatedly used a mapping metaphor to describe Systema Naturae. Linnaeus noted in his "Observations on the three kingdoms of nature" ("Observationes in regna III. naturae") prefacing the work: "I have shown here a general survey of the system of natural bodies so that the curious reader with the help of this as it were geographical table knows where to direct his journey in these vast kingdoms." ${ }^{87}$ In a letter dated July 22, 1738 to Richard Richardson, the Dutch botanist Johan Frederik Gronovius invoked once again the map metaphor: "With [Linnaeus's] Tables we can refer any fish, plant, mineral, to its genus and, subsequently, to its species, though none of us had seen it before. I think

85. Joseph von Rathgeb to Carl Linnaeus, Venice, Italy, 26 Jan I748. Linnean Correspondence online, Letter Lo775: http://linnaeus.cr8.net/Letters/display_txt.php?id_letter=Lo775 (accessed 25 Feb 20II).

86. Johann Georg Gmelin to Carl Linnaeus, Tübingen, Germany, Is Mar 1748. Linnean Correspondence online, Letter Lo890: http://linnaeus.cr8.net/Letters/display_txt.php?id_ letter $=$ Lo890 (accessed 25 Feb 20II).

87. Linnaeus, Systema Naturae (ref. I4), i9. 


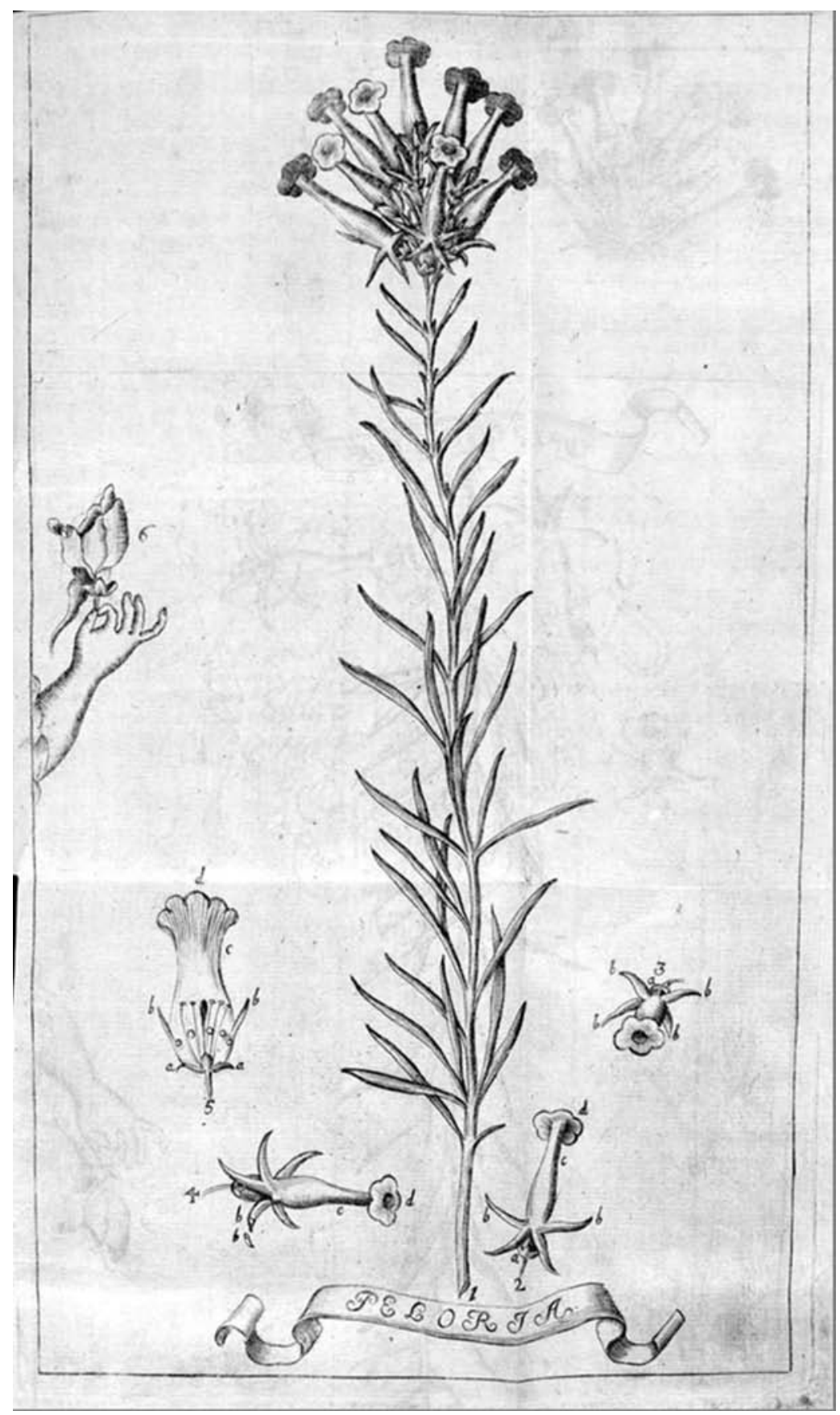

FIG. 13 Illustration of the common toad-flax (now named Linaria vulgaris L.). Source: Carl Linnaeus, De Peloria (ref. 84). By permission of the Linnean Society of London. 
these Tables so eminently useful, that everybody ought to have them hanging in his study, like maps." ${ }^{88}$ Linnaeus used the metaphor, on at least three other occasions: once when talking of his Incrementa Botanices (1753): "And so we have completed the principal epochs of Botany (Botanices fata primaria) in as short a space as possible, as if for a chart to be hung on the wall." ${ }^{89}$ More famously, he also referred to the natural system as a sort of geographical map: in Philosophia Botanica, the five divisions of the natural system (classes, orders, genera, species, and varieties) are likened to the five divisions of geography (realm, province, district, parish, and hamlet), among others. Elsewhere he wrote: "All plants exhibit their contiguities on either side, like territories on a geographical map." "In 1792, Paul Gisecke, one of Linnaeus's students, published a "Tabula genealogico-geographica," which reflected, in a map-like arrangement, the results of morphological comparison that Linnaeus and his students employed in order to establish "natural" affinities. The $\mathbf{1 7 9 2}$ map of the natural system is a clear indication of the epistemological value of Linnaeus's use of visual representations in his work. Using such tools enabled him to work out his conclusions on the natural system of plants.

\section{Diagrams and Tables}

Systema Naturae (1735) is the most striking example of the continuity between Linnaeus's information processing techniques in his private manuscript notebooks and the visual displays in his printed work. The work was in effect the outcome of years of training and learning how to display information on a page effectively. Printed in a very large format, Systema Naturae consisted essentially of three tables classifying the kingdoms of minerals, animals, and vegetables - the last preceded by the dichotomous diagram identifying the twenty-four classes of plants from "Monandria" to "Cryptogamia." Reappropriating the combination of a diagram followed by a table which Linnaeus used to display Tournefort's classification of plants in his student notebook "Manuscripta Medica," Linnaeus displayed his own sexual system in the form of a dichotomous diagram, first tentatively in his catalogues of the Uppsala

88. James Edward Smith, A Selection of the Correspondence of Linnaeus and Other Naturalists, from the Original Manuscripts, vol. 2 (London: Longman, I82I), 174. See also Linnaean Correspondence online, Letter L5624: http://linnaeus.cI8.net/Letters/display_letter.php?id=L5624 (accessed 2I Jul 2OII).

89. Quoted and translated by Heller, "Linnaeus on Sumptuous Books" (ref. 7I), i.

90. Linnaeus, Philosophia Botanica (ref. 73), 40. 
botanical garden (I730s), then with confidence in Systema Naturae. Each of the three tables fits within one double-page spread and here again is found the use of space divided into boxes, the likes of which Linnaeus had experimented with in his early student years.

Even when tables or diagrams do not occur, the descriptions in some of Linnaeus's major works follow a strict visual pattern that enumerates, always in the same order, the main characters of the plant. Hence in Genera Plantarum, the entries for each genus follow an unvarying pattern portraying each flower part, upon which Linnaeus's description is based: namely the calyx, corolla, stamen, pistils, perianth, and seeds. Here, description, as Linnaeus wrote, replaced illustration, and in some ways the literary description followed the same visual analysis of the flowers, much like a diagram would. As Eddy has shown, much of the layout of words and text in Philosophia Botanica is essentially diagrammatic or tabular, expressing "a cognitive framework that was fundamentally spatial."91 The skills Linnaeus learned and developed during his student years were therefore applied throughout his published work, either overtly as in the tables and diagrams, or in more subtle ways, as in the distribution of the text.

With its very visual tabular layout, its illustration of the twenty-four classes of plants, and its analytical drawings, Systema Naturae was clearly designed for the uninitiated naturalist as a guide to the classifications of the natural world. Linnaeus also considered Philosophia Botanica, which he produced partly in response to his students' demands, a useful work for a beginner botanist. ${ }^{92}$ Philosophia Botanica was aimed at a lay audience, and the work became one of the most popular botanical works ever sold. It was reprinted ten times between 1755 and I824, translated in English, German, Spanish, French, and Russian, and was condensed into countless primers of botany. ${ }^{93}$ Among its admirers were Rousseau and Goethe, who reputedly carried Philosophia Botanica in their pockets during their country walks. ${ }^{94}$ It is interesting that these two works, essentially written for beginners, are also the ones which drew

91. Eddy, "Tools for Reordering” (ref. I9), 242.

92. Linnaeus, Philosophia Botanica (ref. 73), "Lectori botanico."

93. B. H. Soulsby, A Catalogue of the Works of Linnaeus (and Publications More Immediately Relating Thereto) Preserved in the Libraries of the British Museum (Bloomsbury) and the British Museum (Natural History) (South Kensington) (London: British Museum, 1933), 4I-42.

94. Lisbet Koerner, "Carl Linnaeus in His Time and Place," in Cultures of Natural History, ed. Nicholas Jardine, Jim A. Secord, and Emma C. Spary (Cambridge: Cambridge University Press, I996), I55. 
most on the pedagogical and commonplacing tradition by using illustrations, tables, and diagrams so successfully.

Conversely, the numerous monographs in Linnaeus's output were especially useful to the specialist, or the confirmed botanist. One could argue then that the published works containing visual representations catered to two specific audiences: on the one hand, to students and lay people at the beginning of their research, or in search of more botanical competency; and on the other hand, to the specialists who worked at the species level. The significant use of images in both Linnaeus's manuscripts and printed works indicates that for him, visual representations had a role to play in the acquisition of knowledge, especially at the early stages, and to some extent at the specialist level. Research can be said to evolve in an endless cycle of ever-more specialized beginnings. When Linnaeus started investigating a particular genus for one of his dissertations, he would start almost from scratch, returning to the previous literature by Ray or Tournefort, and possibly to his own old notebooks. The distinction between the level of beginner and specialist can therefore be difficult to establish, as a specialist continually restarts, and can be described, as a beginner of sorts-albeit at a different, more specialized level.

\section{CONCLUSION}

Linnaeus certainly was not against botanical illustrations as such. He lined the walls of his study in his Hammerby country house with beautiful botanical illustrations. Several of his letters to Ehret thank the German painter for the gift of such images: "I give many and a thousand thanks to you, who are a constant and enduring friend and every year you send me wonderful pictures, drawn glowingly by your hand, and which ornate and embellish the walls of my study and transport visitors into raptures." 95 I have also shown that visual representations such as drawings, tables, diagrams, and maps are

95. Letter from Carl Linnaeus to Georg Dionysius Ehret, I3 Oct 1747; see Linnaean Correspondence online, Letter Lo844: http://linnaeus.ci8.net/Letters/display_txt.php?id_letter=Lo844 (accessed 25 Feb 20II). Linnaeus must have been writing about Ehret's talents, for in a letter dated January 9, I750, Joseph von Rathgeb reflects on Linnaeus's opinion that Ehret makes the most beautiful pictures of plants the world has ever seen; Letter Lioo8: http://linnaeus. cI8.net/Letters/display_txt.php?id_letter=Lioo8 (accessed 25 Feb 20II). And in March 1769, Linnaeus again mentions images of specific species which he had just received from Ehret; Letter L4I9I: http://innaeus.cI8.net/Letters/display_txt.php?id_letter=L4I9I (accessed 25 Feb 20II). 
all very present in Linnaeus's manuscripts and printed output. In the early manuscripts from his student years, the aim was mainly to visualize the information, acting as a memory aid in the commonplacing tradition, but also, importantly, as a research tool, a way to present available data synoptically in order to gain new understanding.

The importance of visualization and memorization and its impact on the way Linnaeus displayed information on the page is something that is striking in all of the early manuscripts, and it undoubtedly resulted in part from his eighteenth-century Swedish education, still firmly focused on the humanist rhetoric and commonplace book method. As a schoolboy, Linnaeus memorized the first names of the botanists he encountered by analogy: in his notes from Rothman's tutorials, Linnaeus writes "Tornefors" (fors being a waterfall in Swedish, and Torneå a place in Lapland) and "Valliant" (or "courageous" in French), perhaps purposefully distorting the French names to fit a mnemonic device. ${ }^{96}$ Later, Linnaeus insisted on numerous occasions on the importance of memory in the work of the botanist. Hence, in Philosophia Botanica he quoted Hermann Boerhaave (I668-I738) by describing botany as "the part of natural science by means of which plants are investigated and remembered most agreeably and with the least trouble." 97 As one progressed in the discipline of botany one should be able to remember more: "A beginner in botany knows the classes, a candidate all the genera, and a master most of the species. The more species a botanist knows, the more outstanding he is." "Fo For Linnaeus, memory needed to be helped on the way, first and foremost by a good classificatory system: "I believe there is hardly anyone born with such a memory that he could retain the genera without a

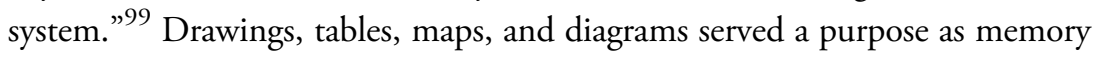
aids and as such they were especially useful for the beginner and for the researcher. Their function was not aesthetic.

Beyond an aid to memory, drawings, tables, maps, and diagrams were also material and practical tools by which classification was literally figured out. The arrangement of data into diagrams or tables helped Linnaeus to think about the relationships between genera or, at a higher level, of orders and classes, to organize them in space, and to find adequate means of classifying

96. Linnaeus, "Commonplace Book" (ref. 43), I83. I thank Staffan Müller-Wille for highlighting this observation.

97. Linnaeus, Philosophia Botanica (ref. 73), 4.

98. Ibid., 256.

99. Müller-Wille and Reeds, "Introduction to Genera Plantarum" (ref. 2), 567. 
them. Such visual representations were therefore tools of analysis. Laid out on the page much like the various assaying instruments in Linnaeus's "Vulcanus Docimasticus," the names of genera could then be rearranged and fitted into a bigger picture through the means of a diagram or table. At the early stage of learning, visual representations were used at the level of "making" as well as "knowing" and were a way to move from perception to memory to experience. ${ }^{100}$ Linnaeus made drawings and classifications in order to know. The jump from memory to experience could not happen without this first step of visualization. Later on, within his classificatory work he could afford to eschew drawing as a method of representation, which was in any case inadequate for descriptions of genera and the relationships between them. Moreover, in Linnaeus's all-encompassing catalogue of nature (Species Plantarum), drawings for all the species represented would have been too numerous to make their production or inclusion possible or useful. At a later date, the map medium enabled Linnaeus to break free of the commonplacing heritage and consider associations by affinities in order to define a natural order of plants.

More concretely, images had a practical function in one of Linnaeus's main concern: the role of botany in economy, a "cameralist plan" that Linnaeus took very seriously, as Koerner has shown. ${ }^{101}$ Alpers successfully demonstrated the untenability of the boundaries between high art and crafts, and the materiality of drawing and image-making. ${ }^{102}$ Linnaeus's textuality-when he was not using images and diagrams, as in his main classificatory workswas always highly visual and technical, following strict organizational patterns. There is a link between this visual imaging-whether through text or images themselves, and whether in print or in manuscript - and the practicalities of botany. I have discussed Linnaeus's keen interest in the structure of things, his ability to display objects laid flat in a way that encourages the reader or viewer to touch them. Bender and Marrinan observed: "The Encyclopedia's preoccupation with technique privileges an imagined, tactile manipulation of things as a powerful mode of correlation." ${ }^{103}$ The same applies to Linnaeus and his approach to botany, which was a hands-on approach. Linnaeus devised a herbarium with loose sheets that could be manipulated and reshuffled at will; he planted herbs and plants according to his sexual system

IOo. Daston, "Scientific Observation" (ref. 3); Smith, "Art, Science, and Visual Culture" (ref. 3).

IOI. Koerner, Linnaeus: Nature and Nation (ref. 45), 79.

IO2. Alpers, Art of Describing (ref. 53), 24.

I03. Bender and Marrinan, Culture of Diagram (ref. 47), 23. 
from I73I in the Uppsala botanical garden; he played around with the way he kept his data on genera on loose sheets, on index cards. ${ }^{104}$ Linnaeus was deeply implicated in the role of botany in the Swedish economy, producing pamphlets and dissertations-all illustrated-on various genera such as tea or mulberry trees which could be acclimatized to grow on Swedish soil. Linnaeus's interest in botany was therefore not solely theoretical and classificatory. There were very concrete and material applications underlying his whole enterprise. The drawings, figures, and diagrams were an integral part of his method in botany. Far from seeing Linnaeus as the botanist who reduced his discipline to text, this view should be nuanced and should take into account the numerous visual representations Linnaeus used throughout his life — in manuscript as well as in print-and reinsert them into a broader understanding of what botany really entailed for this eighteenth-century naturalist.

\section{ACKNOWLEDGMENTS}

Research for this article was supported by a Wellcome Trust Research Project Grant on "Rewriting the System of Nature: Linnaeus's Use of Writing Technologies." I thank Staffan Müller-Wille, who is principal investigator of the project, for his numerous readings and very helpful criticisms of this article; Lynda Brooks and Ben Sherwood at the Library of the Linnean Society of London for their generous help and support; the staff at the University Library of Uppsala; the two anonymous reviewers who provided very useful criticisms and suggestions; and Chiara Ambrosio and Brian Clarke. Versions of this article were presented at the "Colonial Science and Its Histories" seminar held at the Institute of Historical Research, London (December 10, 2010) and at the Third Biennial Conference of the Society for the Philosophy of Science in Practice, Exeter (June 23, 2011).

IO4. Müller-Wille, "Linnaeus' Herbarium Cabinet" (ref. 8I); Müller-Wille and Scharf, "Indexing Nature" (ref. 50). 